\title{
Rappresentazione, percezione e wayfinding. L'architettura per l'università del passato e del presente
}

\author{
Cristina Càndito \\ Alexandra Castro \\ Alessandro Meloni
}

Abstract

II contributo nasce nel contesto di un più ampio studio sui rapporti tra percezione, wayfinding e rappresentazione dell'architettura. In questo articolo abbiamo sviluppato il confronto tra due architetture accomunate dalla stessa funzione come sedi di studio universitario. Si sono sperimentate metodologie qualitative e quantitative per verificare come la percezione visiva permetta di individuare alcune modalità di riconoscimento dei luoghi e di orientamento all'interno di essi. La prima architettura, il palazzo dell'Università di Genova di origini secentesche, è studiata attraverso il metodo di analisi degli spazi visibili da un punto di osservazione (isovista) con l'ausilio di un algoritmo (Grasshopper) capace di individuare l'impronta planimetrica di tali spazi e della loro trasposizione in forma tridimensionale grazie al confronto con la fotografia nodale a $360^{\circ}$. II secondo esempio, la Facoltà di Architettura dell'Università di Porto costruita tra il 1985 e il 1996, è composto da un complesso di edifici che evidenzia immediatamente l'evoluzione del rapporto tra spazio di studio e fruitori. Quella che nel palazzo secentesco era la manifestazione di una gerarchia monumentale che enfatizzava le funzioni rappresentative e celava quelle private, peraltro composte in una originale formula architettonica, si trasforma, infatti, in una volontà di individuazione dei singoli elementi, grazie alla ricerca di una caratterizzazione geometrica all'interno di categorie comuni.

Parole chiave

percezione dell'architettura, wayfinding, università, collegi gesuiti, Alvaro Siza.

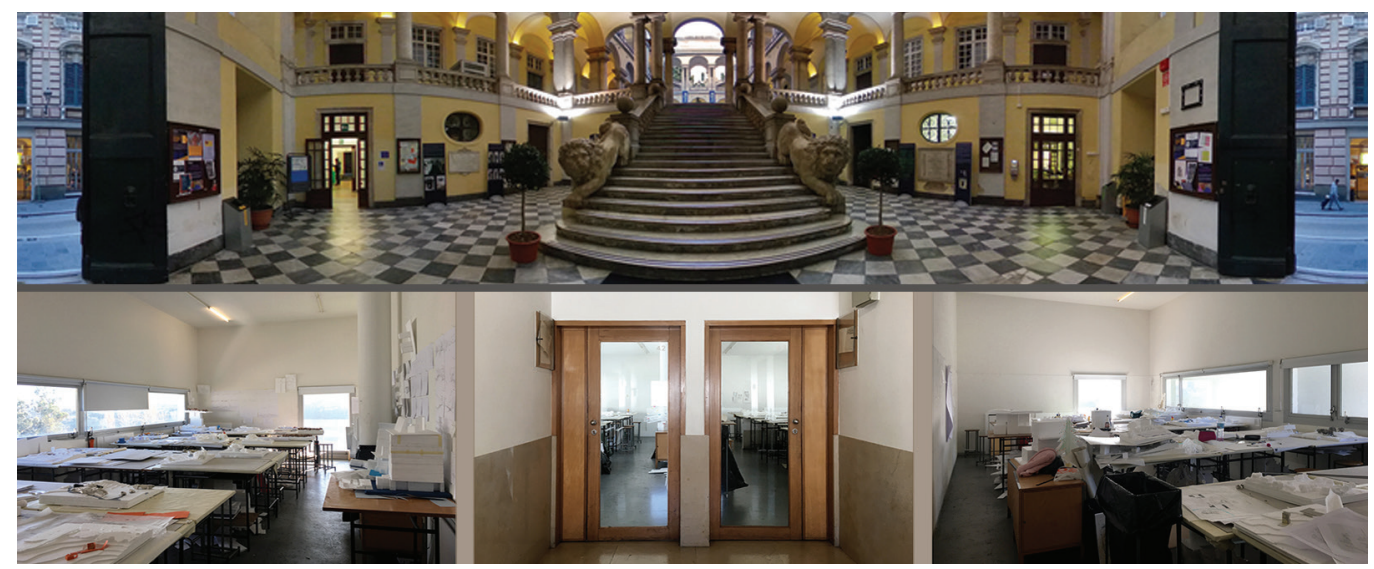




\section{L'esplorazione degli spazi architettonici}

Gli studi sul wayfinding evidenziano le caratteristiche spaziali che favoriscono l'orientamento dei fruitori. Possiamo riconoscere i caratteri di leggibilità di un ambiente, come suggerito da Lynch (1960), oltre a considerare l'interazione tra lo spazio e l'osservatore come proposto da Gibson (1979). Per Golledge (1999) le fasi in cui si articola il processo sono: I) riconoscimento della posizione propria e della destinazione da raggiungere; 2) scelta di un percorso e suo monitoraggio; 3) raggiungimento dell'obiettivo. La loro individuazione può essere analizzata anche attraverso aggiornate prospettive cognitive, neurologiche e architettoniche [Dalton, Hölscher, Spiers 20 I5]. Nel presente studio si sono scelti due edifici universitari costruiti in epoche diverse - il secentesco palazzo dell'Università di Genova e la sede della Facoltà di Architettura di Porto realizzata alla fine del Novecento - che sono stati analizzati con diverse metodologie in grado di svelare le specifiche modalità di orientamento e di riconoscibilità degli ambienti a partire dagli spazi di accesso.

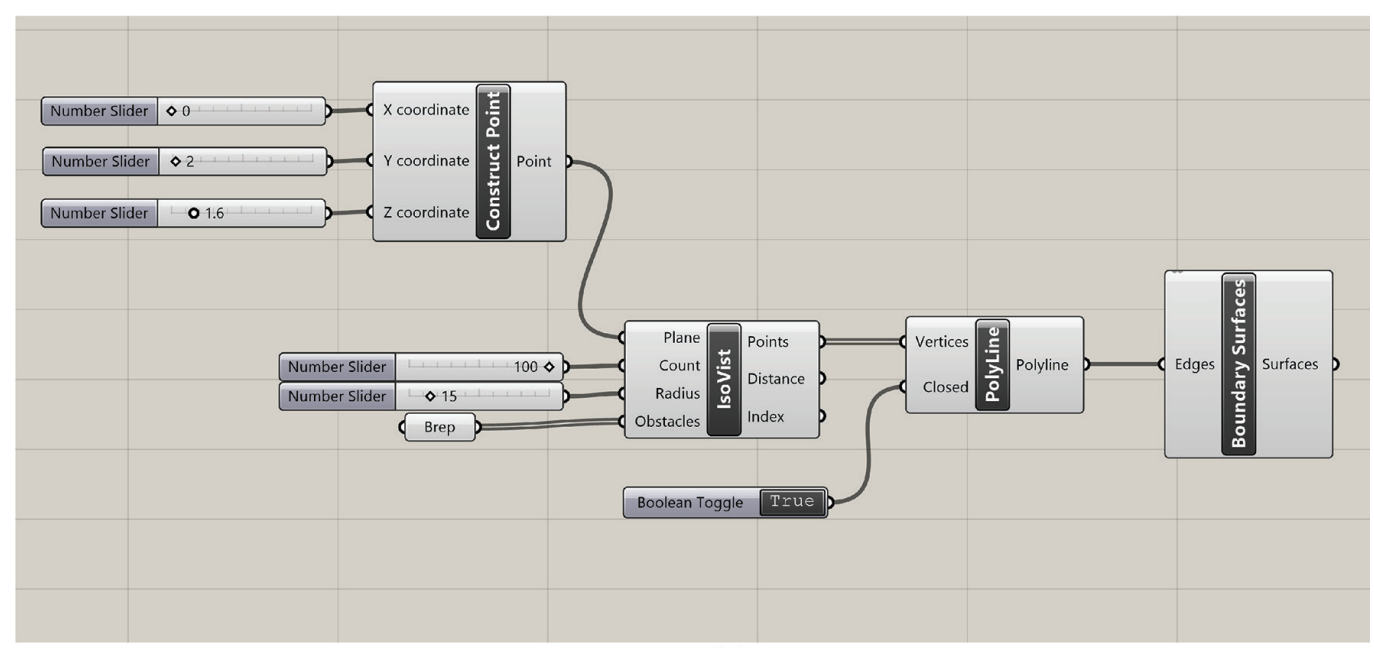

(a)

Fig. I. Palazzo dell'Università di Genova: l'algoritmo di Grasshopper (a) per generare la pianta con isovista (b)

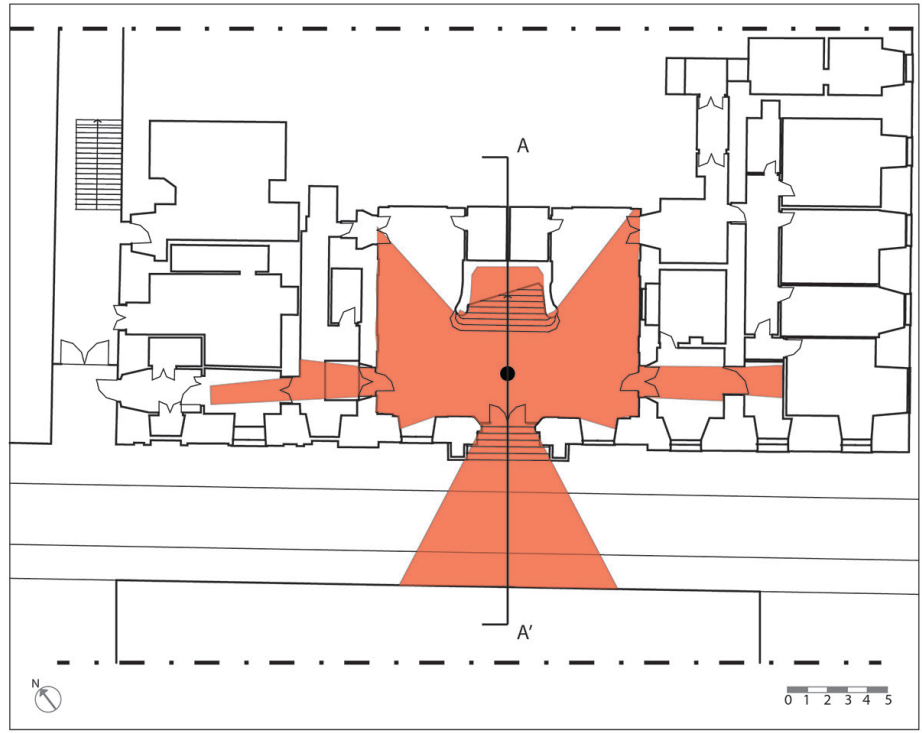

(b) 


\section{Il Palazzo dell'Università di Genova}

II palazzo dell'Università di Genova nasce come sede del Collegio dei Gesuiti attraverso un accordo tra una importante casata genovese, la famiglia Balbi, e la Compagnia di Gesù. La costruzione viene avviata nel 1633 su progetto di Bartolomeo Bianco (I579-1640), con interventi di Orazio Grassi ( 583 I 654), rettore del collegio dal I646, e di altri protagonisti della scena genovese che hanno condotto alla realizzazione di un edificio determinato da un originale compromesso tra architettura locale e strutture analoghe e coeve [I].

\section{Analisi della percezione dello spazio: l'isovista}

Gibson (1979) evidenzia come lo spazio definisca un linguaggio capace di comunicare informazioni, recepite e rielaborate dall'osservatore, per ottenere dati utili per il riconoscimento dell'ambiente [2]. Uno dei metodi per visualizzare queste caratteristiche è quello che prevede l'impiego delle isoviste. L'isovista viene definita come l'insieme di tutti gli elementi visibili da un dato punto di osservazione nello spazio. La forma e le dimensioni di un'isovista cambiano con la posizione dello stesso [Benedikt 1979].

L'analisi con il metodo delle isoviste è uno strumento potenzialmente utilizzabile nella progettazione, in quanto permette di verificare il rapporto visivo tra soggetto fruitore e spazio, che può contribuire ad individuare alcune caratteristiche dell'ambiente capaci di influenzare la percezione.

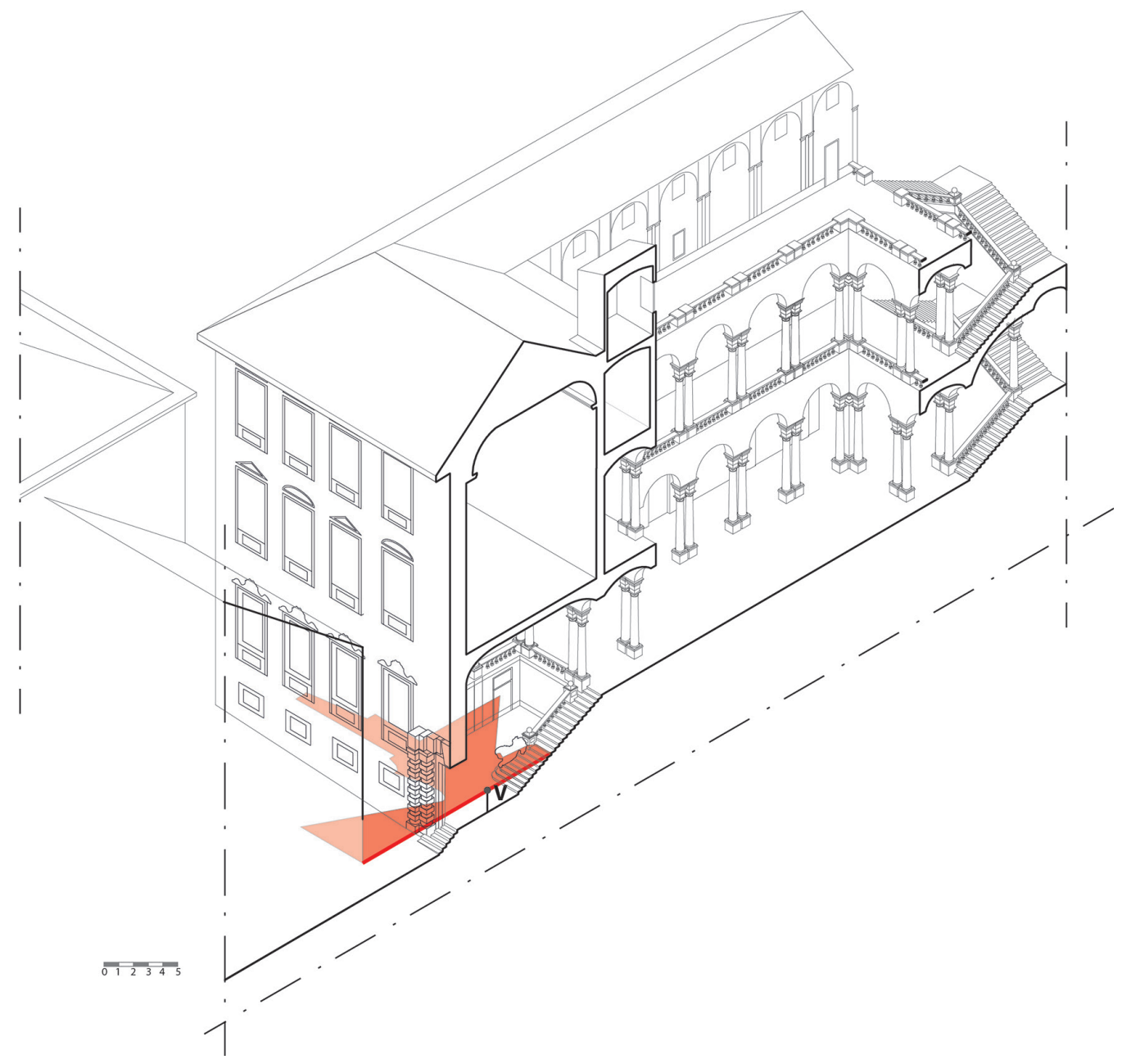


Si possono evidenziare alcuni fattori del ruolo dell'isovista riguardo all'orientamento [Chen, Lin, Chen 2016]:

- area relativa: si tratta di un parametro, in base a cui varia la misura dei raggi visuali e quindi l'ampiezza dell'area che viene valutata come direttamente proporzionale alla sensazione di sicurezza all'interno dello spazio.

- convessità: definisce la compattezza dell'ambiente, poiché il grado di frammentazione dell'immagine percepita può incidere notevolmente sulla comprensione dello spazio.

Le sperimentazioni in questo ambito si sono spesso concentrate sull'analisi bidimensionale delle isoviste, focalizzandosi soprattutto sulla visione planimetrica [Nagy 20 I 7]. In un recente studio [Ünlü et al. 2019] si auspica lo sviluppo di un approccio esteso alla tridimensionalità, considerando lo spazio che ha come centro il punto di vista dell'osservatore [3].

Nel presente studio abbiamo applicato i citati principi ad un edificio universitario, in analogia con precedenti ricerche [Ünlü et al. 2019], ma con caratteristiche peculiari per la sua costruzione nel XVII secolo. L'atrio del palazzo dell'Università di Genova è il volume principale su cui ci siamo concentrati per la sua funzione di accesso: si tratta di uno spazio voltato a doppia altezza, con un monumentale scalone settecentesco che conduce ai livelli superiori. Lo strumento impiegato per generare la figura è stato Grasshopper (plugin incorporato in Rhinoceros dalla versione 6.0), (fig. Ia), in cui si trova il componente Isovist che individua i punti generati dall'intersezione tra il fascio di rette proiettanti, con origine il centro della visione, e la rappresentazione in pianta dei volumi all'interno dello spazio in oggetto. Ottenuti questi punti è possibile utilizzarli per creare la polilinea che definirà il perimetro dell'area isovista. Si tratta di un sistema dinamico, in quanto cambiando i valori delle coordinate del punto di riferimento è possibile osservare il modificarsi della configurazione.

Abbiamo, quindi, tracciato quella figura piana che permette di individuare gli elementi visibili dall'atrio, dati gli ostacoli e l'ampiezza del campo visivo (fig. I b). II punto di vista è stato individuato vicino all'ingresso per simulare il posizionamento dell'utente nel luogo in cui viene avviata la fase di orientamento allinterno della struttura. La planimetria mostra la forma complessa dell'area isovista e come l'atrio risulti quasi totalmente visibile ad eccezione di alcune zone d'ombra create dalla presenza imponente della scalinata e della coppia di leoni laterali realizzati nel Settecento da Domenico Parodi. L'area esaminata non si limita soltanto all'atrio ma risulta più ampia e permette di osservare spazi laterali e ambiente esterno, di cui l'edificio di fronte (annesso del palazzo Reale, ex palazzo di Stefano Balbi) costituisce un margine frontale.

II metodo bidimensionale evidenzia notevoli aspetti legati all'osservazione dello spazio architettonico, ma non trasmette informazioni sufficienti per una sua comprensione globale. Per integrare la lettura si è posizionato lo schema bidimensionale all'interno di uno spaccato assonometrico (campitura arancione in fig. 2), in modo da poter intuire come assumano importanza le qualità spaziali, che la sola analisi bidimensionale non permette di valutare propriamente.

\section{Fotografia panoramica e wayfinding}

L'analisi spaziale può costituire, dunque, un progresso nel procedimento delle isoviste. Per questo abbiamo cercato di integrare l'informazione planimetrica con lo strumento della fotografia panoramica ottenuta con i procedimenti di fotografia nodale.

La proiezione equirettangolare (fig. 3) fornisce un'immagine d'insieme che appare distorta nella sua visione come rappresentazione statica, ma che acquista efficacia nella sua esplorazione dinamica attraverso strumenti di viewer a $360^{\circ}$. La trasformazione in proiezione cubica (fig. 4) può, inoltre, permettere una migliore riconoscibilità degli elementi nelle immagini statiche, senza dover necessariamente ricorrere alla pur suggestiva dimensione immersiva. Abbiamo individuato un ulteriore implemento in senso tridimensionale nella trasposizione degli spazi visibili tratti dalla fotografia panoramica in una rappresentazione come quella dello spaccato assonometrico (fig. 5). Con l'estrapolazione del principale volume dell'isovista in un esploso assonometrico possiamo ancor meglio descrivere i componenti che si 
Fig. 3. Panorama con ripresa all'atrio: proiezione equirettangolare.
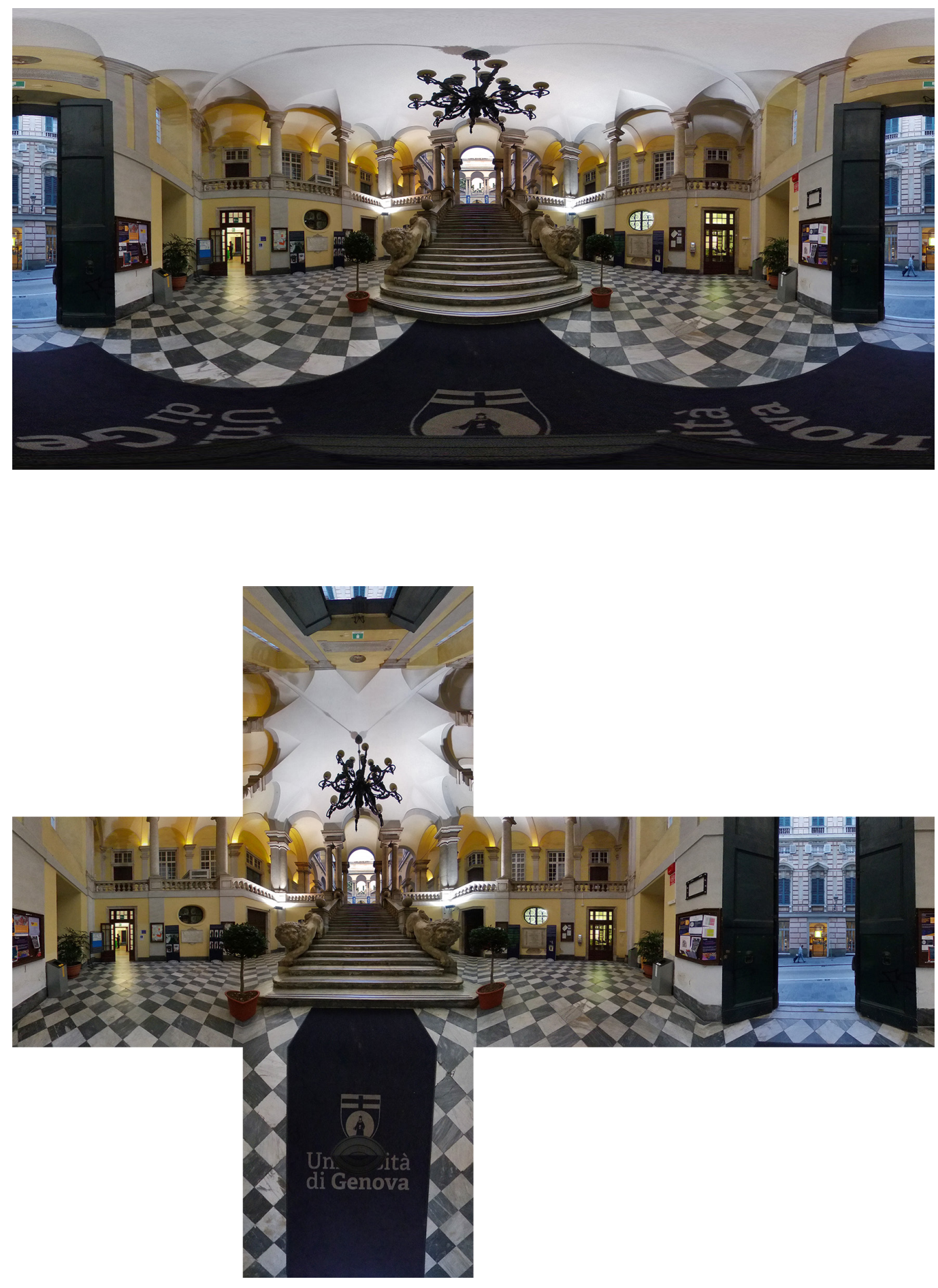
presentano al visitatore che accede dall'atrio (campiture gialle). Lo sguardo corre lungo le logge superiori laterali dell'atrio, con colonne semplici, per proseguire nei portici del cortile, caratterizzati dai più possenti sostegni delle colonne binate, ideate forse su modello del collegio dei Gesuiti di Brera di Milano [Bösel 2012, pp. 7I-89].

Nella porzione alta dello spazio che incornicia l'atrio, le volte a vela delle logge e del portico sembrano allungarsi nelle unghie della volta dell'atrio stesso. È il citato scalone assiale a indicare la direzione che conduce al cortile, con il suo squarcio di cielo, e giunge al suo margine opposto con la scala a forbice che serve i due piani superiori.

La rappresentazione e la delimitazione dello spazio dell'isovista si presentano complesse [4]; per questo motivo, bisogna ricorrere a diverse proiezioni e integrare lo spaccato con sezioni longitudinali e trasversali (figg. 5,6). Peraltro, si è scelto di aggiungere campiture di spazi che, pur non visibili, sono perfettamente intuibili dall'osservatore, come ad esempio le porzioni inferiori delle pareti delle logge laterali (sotto la linea azzurra che ha origine nel punto $P$ in fig. 5) e il completamento delle pareti del portico del cortile, in realtà visibile nel solo cono compreso tra le proiettanti (linee arancioni in fig. 6).

Alcune porzioni degli spazi superiori sono oscurate dagli elementi verticali (vedi proiettanti arancioni in fig. 5), ma occorre osservare come sia proprio lo spostamento dell'osservato-

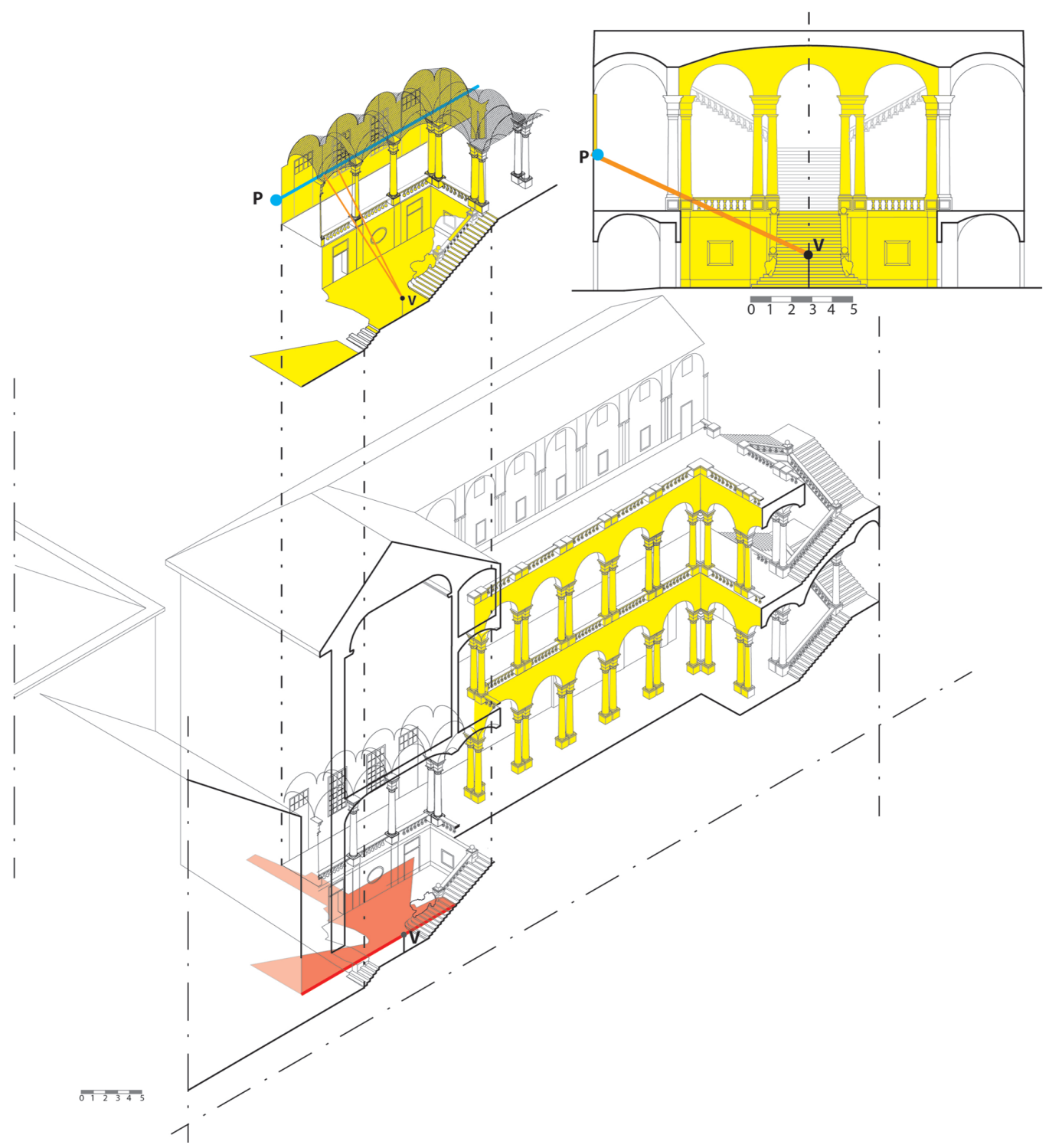


re a permettere di leggere lo spazio nella sua interezza, integrando le parti momentaneamente non visibili.

Dall'atrio sono percepibili molti accessi delle aule del collegio, affacciati alle logge e ai portici, mentre non si scorgono le finestre delle abitazioni dei padri (campitura grigia in fig. 6), arretrate e affacciate sulla copertura dei portici del secondo ordine. Le parti private nei coevi collegi gesuitici si trovano di norma disposte attorno ad un secondo cortile privato, la cui assenza a Genova costituisce la più significativa peculiarità, causata dal terreno in pendio, in una conformazione già sperimentata in altri palazzi locali [5]. Per lo stesso motivo, il cortile si trova in una posizione elevata rispetto all'atrio, che si presenta, quindi, non solo come accesso monumentale, ma quale luogo di osservazione privilegiato per la distribuzione dell'edificio, in linea con alcune attuali indicazioni del wayfinding [Dalton, Hölscher, Spiers 20 I5]. Dal cortile del livello superiore, quindi, si svelano interamente i due ordini di logge, ma continuano a rimanere celate le parti private del collegio, proprio come se si affacciassero ad un altro cortile privato.

\section{La Facoltà di Architettura di Porto}

L'analisi di alcune caratteristiche della Facoltà di Architettura di Porto, realizzata tra il 1985 e il 1996 da Álvaro Siza (nato nel 1933), può permettere di confrontare i dispositivi architettonici che contribuiscono all'orientamento e al riconoscimento dello spazio. Occorre qui considerare non un singolo edificio, ma il suo complesso che si costituisce, a partire dalla preesistente Quinta da Póvoa (inizio XX secolo), all'interno di un vasto terreno ceduto dall'Università di Porto.

Su questo articolato progetto [6] si forniscono qui i soli cenni necessari per definire le caratteristiche di orientamento e riconoscibilità degli spazi. Un originale tracciato regolatore (fig. 7) permette di leggere un insieme di relazioni geometriche che mettono in rapporto i nuovi edifici con la casa della Quinta da Póvoa e il padiglione Carlos Ramos progettato da Álvaro Siza tra 1985 e il 1986 e localizzato nel giardino ad una quota elevata.

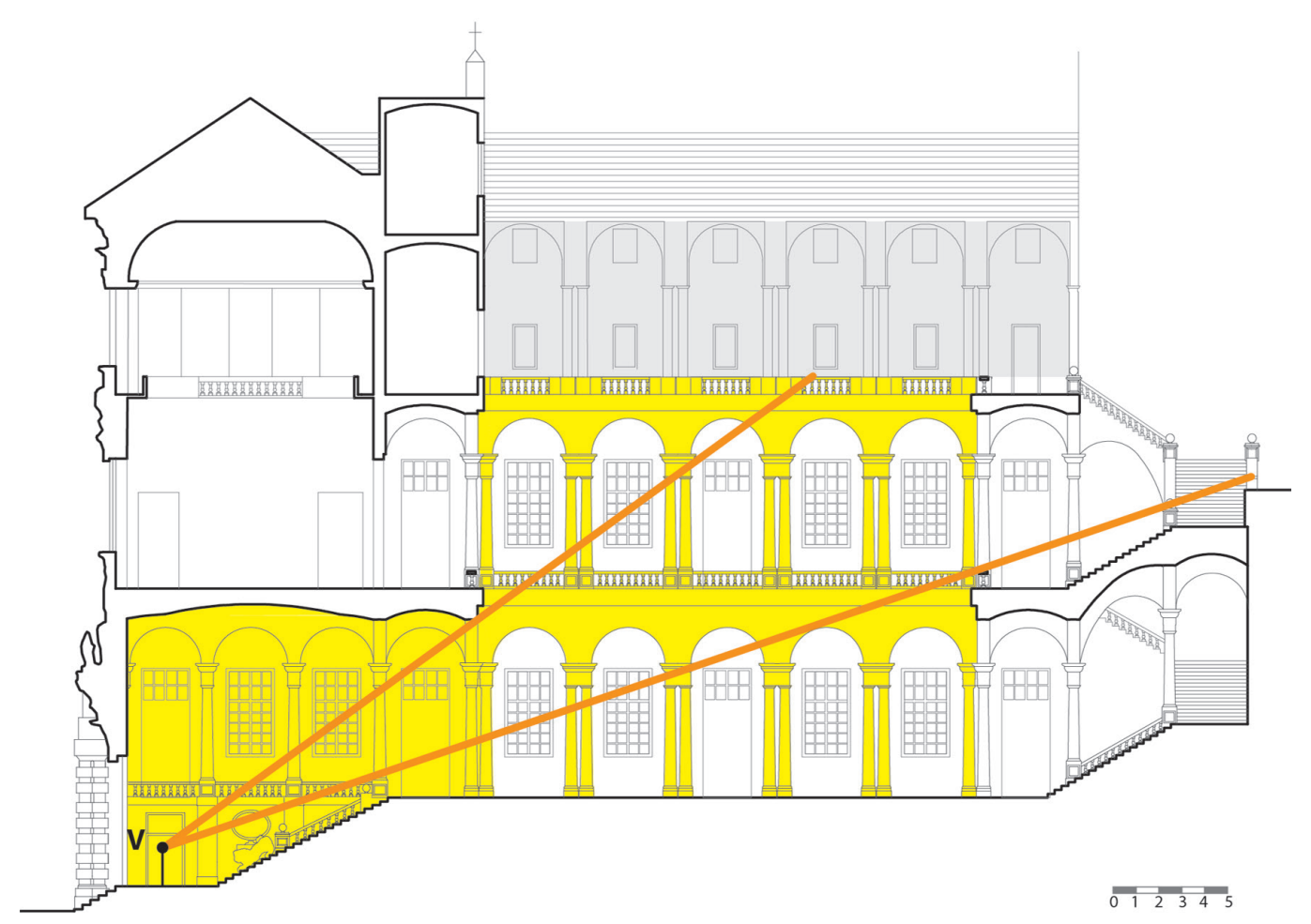


Fig. 7. Facoltà di

Architettura, Porto:

studio planimetrico

Siza, Dias 2003, p. I 47]

In basso a destra: casa

della Quinta da Póvoa.

In alto un accenno del

Padiglione Carlos Ramos.

Fig. 8. Pianta del livello 2: <https://repositoriotematico.up.pt).

Abbiamo aggiunto

l'indicazione delle scale (in

rosso), degli accessi (pallin

blu), del corridoio del

livello 0 (tratteggio) e delle

aule dell'ultimo piano della torre 3 (tratteggio verde).
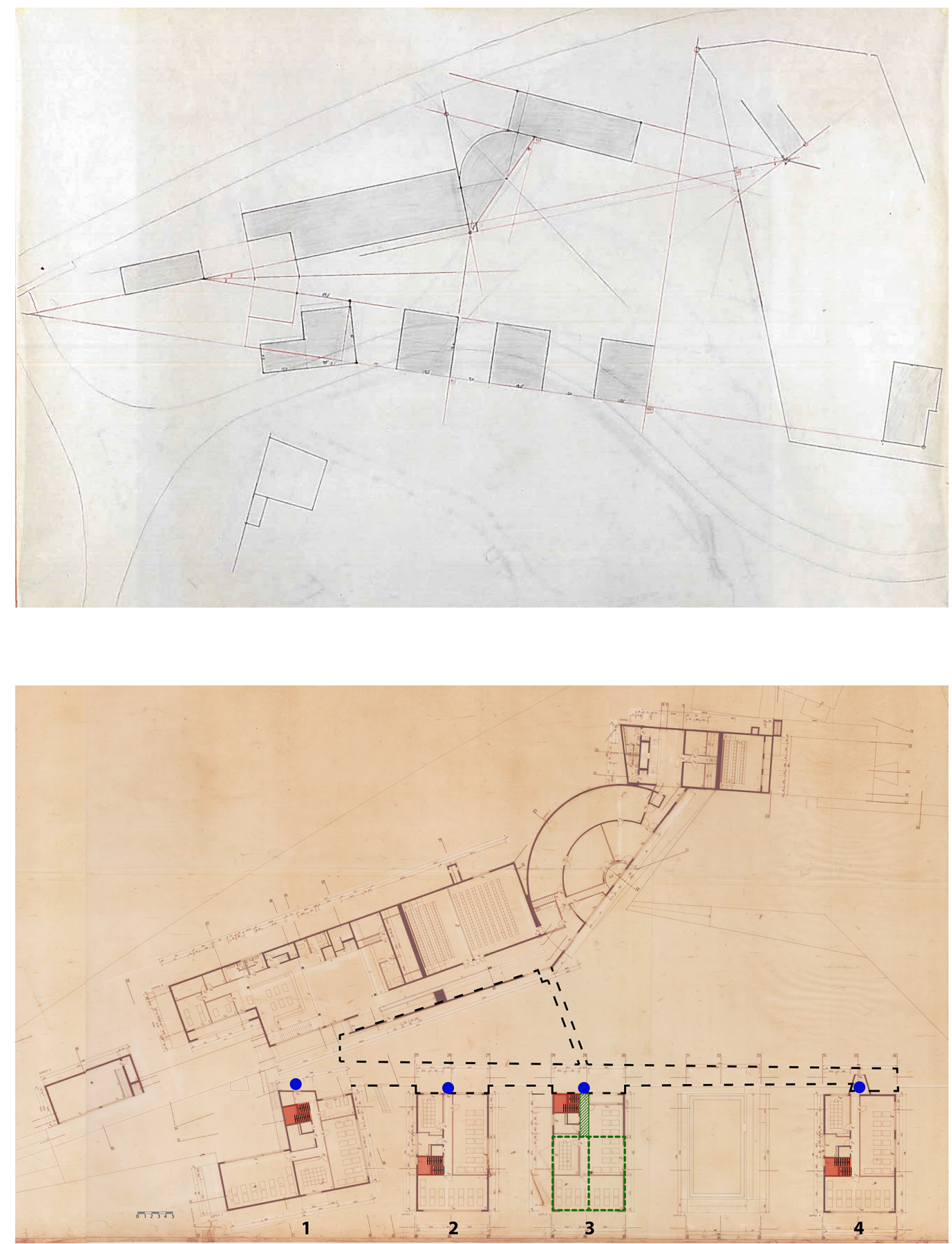
I quattro edifici isolati rivolti verso sud, dove si trovano le aule e gli uffici degli insegnanti, oltre a stabilire una continuità volumetrica con la casa madre, permettono una transizione di scala che mette in relazione le piccole case novecentesche, localizzate a quota bassa sul lungo fiume, con le retrostanti e recenti torri del centro città.

L'edificio lungo più compatto localizzato a nord, che ospita i servizi amministrativi, gli auditori, lo spazio espositivo e la biblioteca, presenta un diverso orientamento, proteggendo dalla retrostante strada i volumi delle aule e lo spazio del cortile di accesso, quest'ultimo assimilabile nelle sue funzioni all'atrio di ingresso. È, infatti, da questo luogo che si ha un colpo d'occhio delle funzioni principali del complesso, a costituire l'affaccio delle torri, le quali simili, ma non uguali tra loro - si allineano con altezza crescente.

I loro singoli accessi si differenziano morfologicamente proprio per consentire una immediata riconoscibilità (figg. 8, 9): nella torre I si ha una sporgenza coperta da un terrazzino, nelle torri 2 e 3 si accede da ingressi diversamente posizionati sulla facciata, mentre nella torre 4, la più alta, si entra da un volume tronco piramidale.

La stessa concezione governa gli accessi alle torri attraverso il lungo corridoio interno di distribuzione al livello inferiore (fig. I0), su cui si aprono una varietà di rientranze che permettono la loro riconoscibilità durante la percorrenza. Un ulteriore elemento di orientamento è costituito dalla rastremazione del corridoio stesso, che costituisce una prospettiva accelerata o rallentata a seconda dello stesso verso di percorrenza.

La differenziazione degli spazi come caratteristica espressiva è perseguita anche nel posizionamento delle scale interne: in mezzo all'edificio nelle torri 2 e 4 ed attestate verso la facciata, ma diversamente configurate, nelle torri I e 3 (fig. 8).

Le stesse aule si distinguono tutte per la diversa conformazione e orientamento delle finestre. Si prendono ad esempio le due aule collocate all'ultimo piano della torre 3, i cui accessi simmetrici (figg. 8, II) potrebbero preludere ad un'analoga simmetria interna, che invece è negata dalla posizione delle finestre dello sfondo e dalla presenza dei brise soleil a nastro che proteggono dal sole le finestre rivolte ad ovest e forniscono una diversa natura della luce naturale.

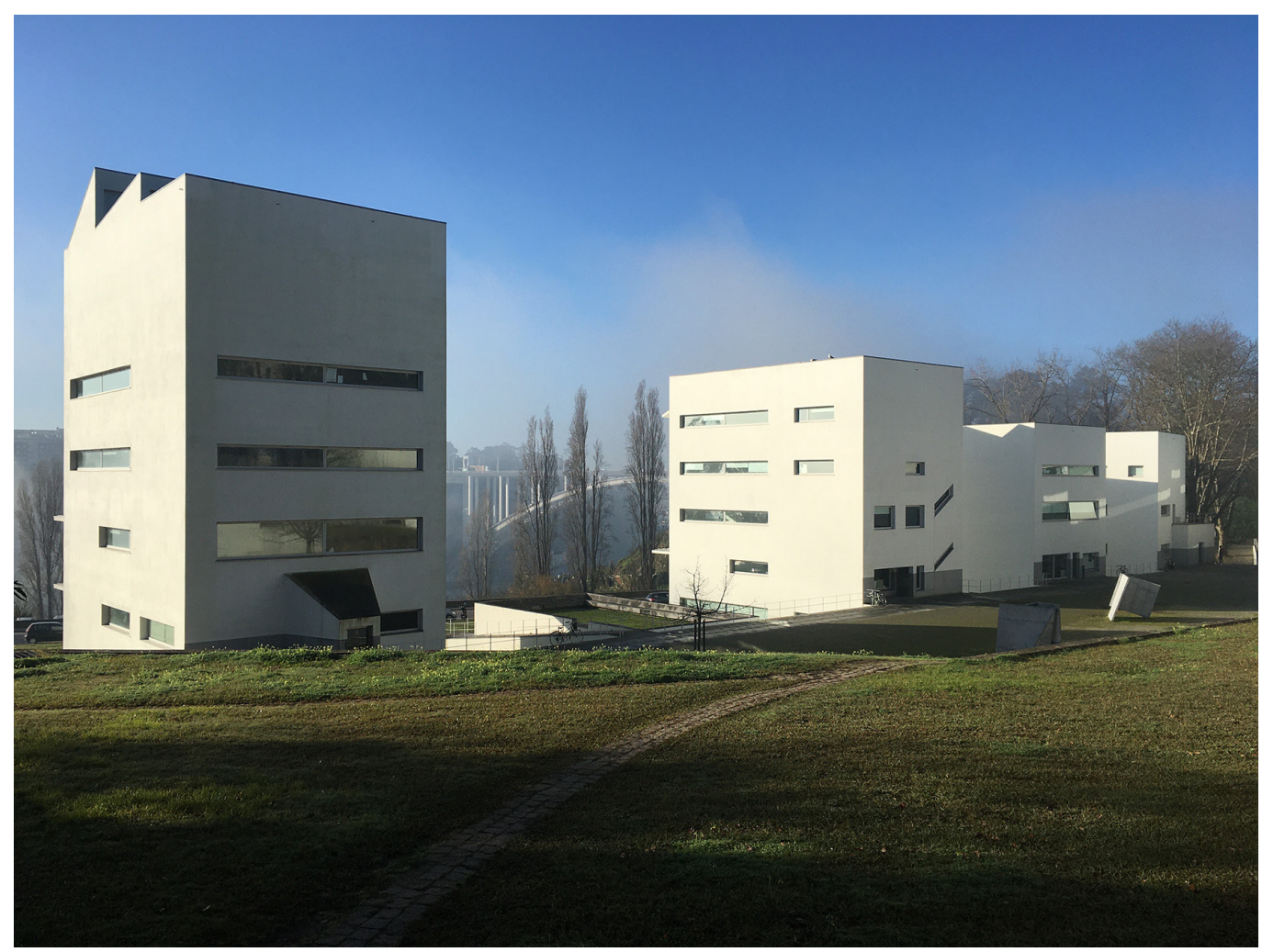




\section{Conclusioni. I luoghi di studio: confronto tra antico e contemporaneo}

L'analisi di alcune caratteristiche di orientamento e riconoscibilità applicata a due architetture caratterizzate dalla stessa funzione ha permesso di effettuare un confronto, pur parziale, sulla diversa concezione degli spazi di studio nel passato e nel presente. Si sono applicati diversi metodi, quantitativi e qualitativi, principalmente agli ambienti di accesso, per verificare come la percezione visiva nell'esperienza architettonica si basi anche sul riconoscimento dei luoghi e sull'orientamento all'interno di essi. Pur essendo circoscritta agli esempi considerati e alle immagini statiche senza comprendere le simulazioni dinamiche, l'analisi conduce al riconoscimento del passaggio da una architettura quale espressione di celebrazione, esemplificata dal secentesco atrio del palazzo dell'Università di Genova - capace di evidenziare gli aspetti pubblici e celare quelli privati - alla varietà spaziale offerta dagli accessi e dalla distribuzione orizzontale e verticale delle torri, nonché dalla stessa configurazione delle aule riscontrabile nella Facoltà di Architettura di Porto, un contemporaneo complesso architettonico capace di esprimere una evidente attenzione verso i fruitori degli spazi e di riconoscere il procedimento dinamico dell'esplorazione architettonica.

Fig. I 0.1 diversi accessi a livello 0 (foto di $\mathrm{A}$. Castro).

Fig. I I. Le aule all'ultimo livello della torre n. 3: a) aula esposta a sud-est affacciata sul giardino della Quinta da Póvoa e il fiume;

b) ingresso;

c) aula esposta a sud-oc) vest afacciata sulfiume e sul cortile dingresso

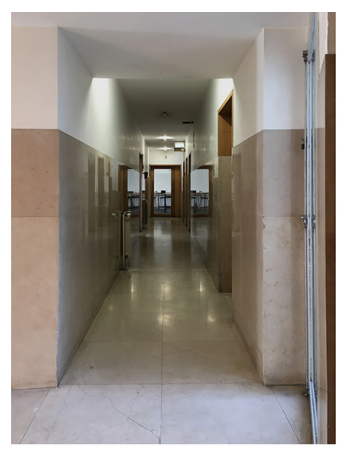

(a)

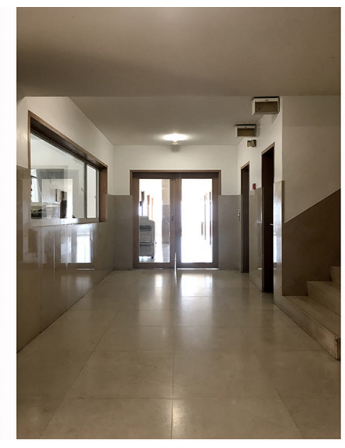

(b)

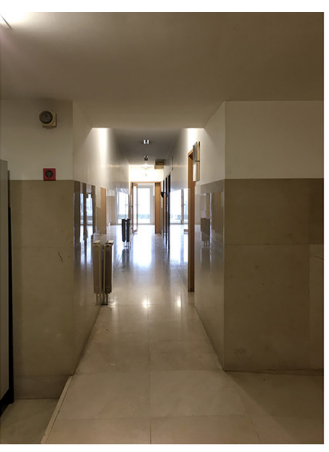

(c)

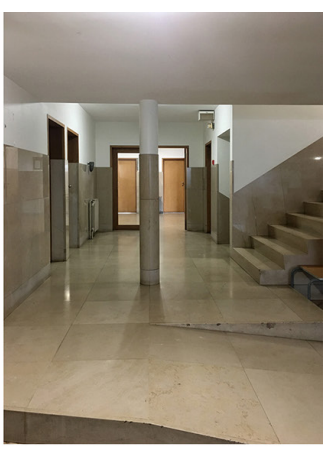

(d)

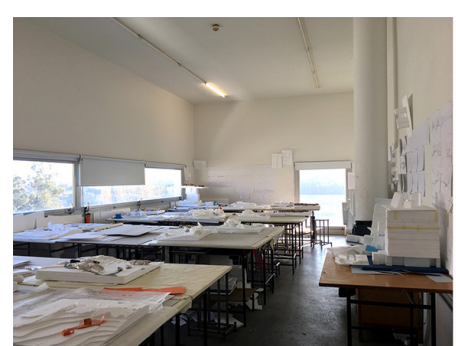

(a)

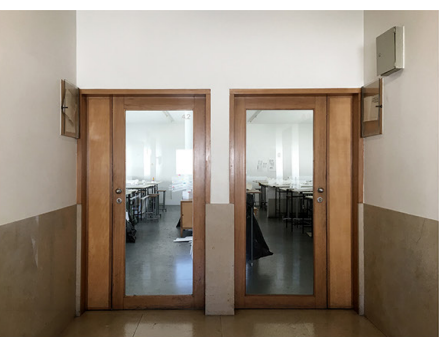

(b)

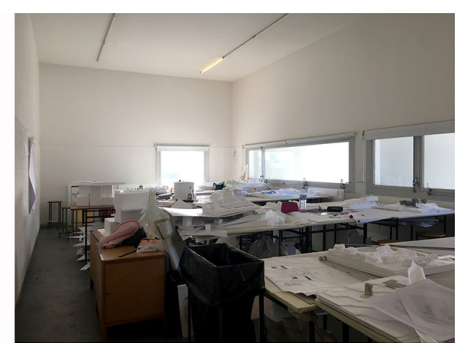

(c)

\section{Ringraziamenti}

Lo studio è stato condotto parzialmente con i fondi della ricerca P.R.A. 2018 (Progetti di Ricerca dell'Ateneo di Genova, intitolato "La rappresentazione e i metodi inclusivi per la valorizzazione dell'architettura") coordinata da C. Càndito.

II contributo è stato concepito ed elaborato in collaborazione, ma il paragrafo Analisi della percezione dello spazio: l'isovista è stato scritto da Alessandro Meloni, il paragrafo La Facoltà di Architettura di Porto da Alexandra Castro e il resto da Cristina Càndito.

Note

[I] Per le diverse versioni di progetto, si veda: [Colmuto Zanella, De Negri 1987, pp. 209-2I I]; per l'architettura gesuitica [Zamora et al. 20 I2], con bibliografia precedente.

[2] Gibson [Gibson 1979, pp. 249-250] descrive come gli ambienti siano composti da elementi invarianti, componenti che persistono all'interno di uno spazio e che facilitano l'orientamento.

[3] Vengono evidenziate caratteristiche spaziali legate al rapporto tra altezza e larghezza del volume, alla sua permeabilità, al rapporto tra pieni e vuoti e alle aperture portatrici di illuminazione naturale [Ünlü et al. 20I9, cap.l. I, s.p.]. 
[4] $\grave{E}$ in corso di studio un'implementazione attraverso un automatico collegamento tra modello virtuale e fotografia panoramica.

[5] Ad esempio in Palazzo Doria Tursi ( 1564) di Domenico e Giovanni Ponzello per Nicolò Grimaldi.

[6] Si rimanda a: Siza, Diaz 2003; Trigueiros 1995; Márquez Cecilia, Levene 1994.

\section{Riferimenti bibliografici}

Benedikt Michael (1979). To Take Hold of Space: Isovists and Isovist Fields. In Environment and Planning B, 6( I), pp. 47-65.

Càndito Cristina (2005). Occhio, misura e rilievo. Gli strumenti ottici e catottrici per l'architettura e il recupero del Collegio dei Gesuiti a Genova. Firenze: Alinea (I ed. Genova 200 I).

Chen Chih-Hung, Lin Ting-Ju, Chen Chih-Yu (2016). From Isovist to Spatial Perception: Wayfinding in Historic Quarter. In Environment-Behaviour Proceedings Journal (E-BPJ), I (3), 300-3 I 0 <https://doi.org/l 0.2 I 834/e-bpj.vl i3.374>.

Colmuto Zanella Graziella, De Negri Emmina (1 987). L'architettura del collegio. In Lamera Federica, Pigafetta Giorgio. II Palazzo dell'Università di Genova. Il collegio dei Gesuiti nella Strada dei Balbi. Genova: Università degli Studi di Genova, 209-275.

Dalton Ruth, Hölscher Christoph, Spiers Hugo J. (20I5). Navigating Complex Buildings: Cognition, Neuroscience and Architectural Design. In Gero John S. Studying Visual and Spatial Reasoning for Design Creativity. Dordrecht: Springer Netherlands, pp. 3-22. <https://doi.org/I0.1007/978-94-017-9297-4_I>.

Gibson James Jerome (1979). The ecological approach to visual perception. Boston: Houghton Mifflin Company.

Golledge Reginald G. (1999). Wayfinding Behavior: cognitive mapping and other spatial processes. Baltimora:The Johns Hopkins University Press.

Lynch Kevin (1960). The image of the city. Cambridge, Massachusetts: MIT Press.

Márquez Cecilia Fernando, Levene Richard (1994). Álvaro Siza Vieira 1958- 1994. El Croquis, 68/69, 1994.

Nagy Danil (2017). View analysis with isovist. Generative Medium (blog). Catalog of lecture notes, technical tutorials, and other content from an advanced computational design course at Columbia University's Graduate School of Architecture, Planning and Preservation (GSAPP). >https://medium.com/generative-design/view-analysis-with-isovist-587fcel 49956>.

Siza Álvaro, Dias Adalberto (2003). O Edifício da faculdade de Arquitectura da Universidade do Porto. Percursos do Projecto. Porto: FAUP Publicaçõe.

Trigueiros Luiz (1995). Álvaro Siza. 1986-1995. Lisboa: Editorial Blau.

Ünlü Alper, Edgü Erincik, Şalgamcioglu Mehmet Emin, Çanakçioglu Gul, Yilmaz Emir Atakan (20। 9). Isometric measurands on perceived spaciousness: exploring volumetric isovist. In 12 th Space Syntax Symposium, p. I 32. Beijing.

Zamora Álvaro, lbáñez Fernández Javier, Mainar Criado Jesus (20 I 2). La arquitectura jesuítica. Actas del Simposio Internacional. Zaragoza 9-II diciembre 20 10. Zaragoza: Institución Fernando el Católico, pp. 7I-89.

\section{Autori}

Cristina Càndito, Università di Genova, cristina.candito@unige.it

Alexandra Castro, Universidade do Porto, macastro@arq.up.pt

Alessandro Meloni, Università di Genova, alessandro.meloni@edu.unige.it

Per citare questo capitolo: Càndito Cristina, Castro Alexandra, Meloni Alessandro (2020). Rappresentazione, percezione e wayfinding. L'architettura per l'università del passato e del presente/Representation, perception and wayfinding. University Architecture of the past and present. In Arena A., Arena M., Brandolino R.G., Colistra D., Ginex G., Mediati D., Nucifora S., Raffa P. (a cura di). Connettere. Un disegno per annodare e tessere. Atti del $42^{\circ}$ Convegno Internazionale dei Docenti delle Discipline della Rappresentazione/Connecting. Drawing for weaving relationships. Proceedings of the 42th International Conference of Representation Disciplines Teachers. Milano: FrancoAngeli, pp. | 820-184|. 


\title{
Representation, Perception and Wayfinding. University Architecture of the Past and Present
}

\author{
Cristina Càndito \\ Alexandra Castro \\ Alessandro Meloni
}

Abstract

The contribution was born in the context of a wider study on the relationships between perception, wayfinding and representation of architecture. In this paper, we developed the comparison between two architectures that share the same function as university study locations. Qualitative and quantitative methodologies have been tested to verify how visual perception allows to identify some ways of recognizing places and orientation within them. The first architecture, the palace of the University of Genoa built in the seventeenth-century, is studied through the analysis method of the spaces visible from an observation point (isovist), using an algorithm capable of identifying the planimetric imprint of these spaces (Grasshopper) and its transposition in three-dimensional form thanks to the comparison with nodal photography at $360^{\circ}$. The second example, the Faculty of Architecture of the University of Porto built around 1990, is composed by a complex of buildings, which immediately highlights the evolution of the relationship between the space of study and the users. What in the seventeenth-century palace was the manifestation of a monumental hierarchy that emphasized the representative functions and hid the private ones, composed in an original architectural formula, is transformed into a desire to identify the individual elements thanks to the search for geometric differentiation within common categories.

Keywords

architectural perception, wayfinding, university, Jesuit colleges, Alvaro Siza.

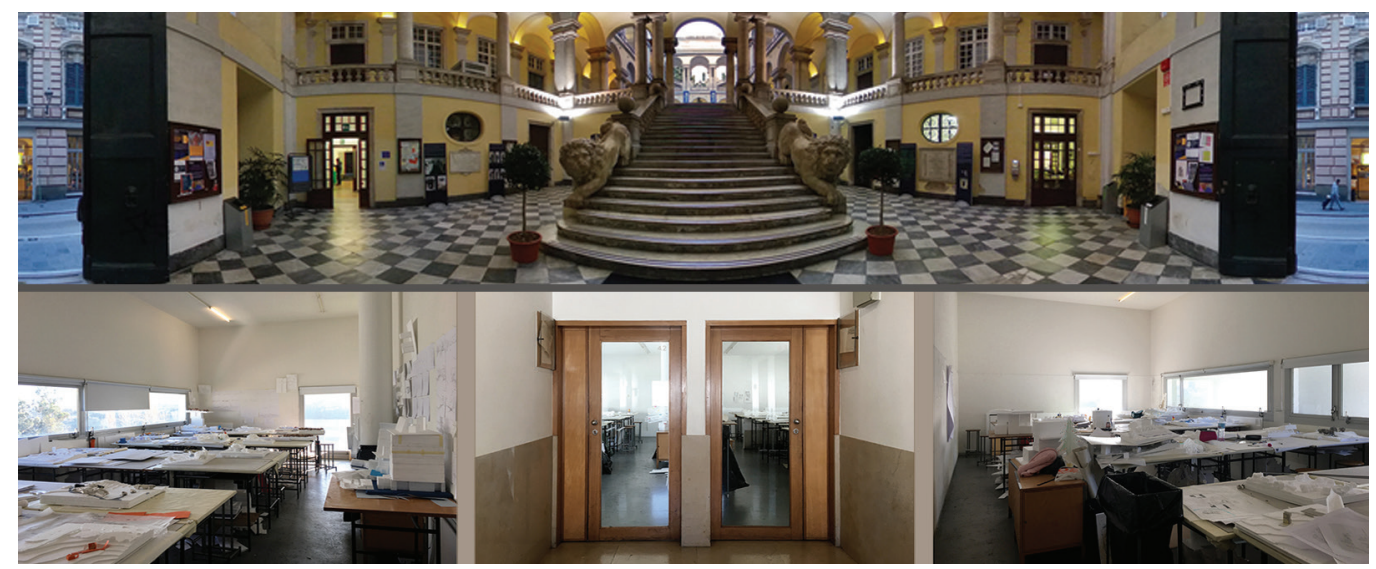




\section{The exploration of architectural spaces}

The wayfinding studies highlight the spatial characteristics that favour the orientation of the users. We can recognize the legibility characters of an environment, as suggested by Lynch (1960), as well as considering the interaction between space and observer as proposed by Gibson (1979). For Golledge (1999) the phases in which the process is divided are: I) recognition of one's position and the destination to be achieved; 2) choice of a route and its monitoring; 3) reaching of the goal. Their identification can also be analysed through updated cognitive, neurological and architectural perspectives (Dalton, Hölscher, Spiers 20 I5). In the present study, two university buildings constructed in different periods were chosen -the seventeenth-century palazzo of the University of Genoa and the seat of the Faculty of Architecture of Porto built at the end of the twentieth century- which were analysed with different methods capable of revealing the specific methods of orientation and recognisability of the environments starting from the access spaces.

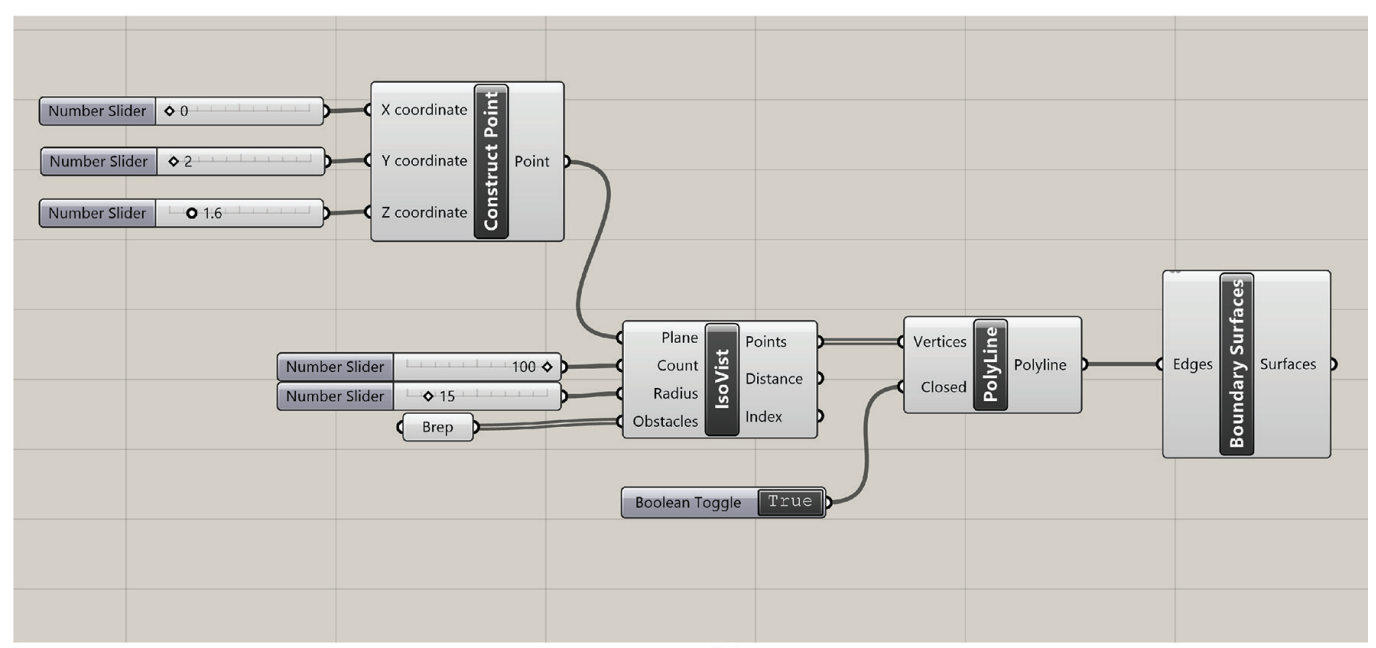

(a)

Fig. I. Palace of the University of Genoa: the Grasshopper algorithm (a) to generate the plan with isovist (b)

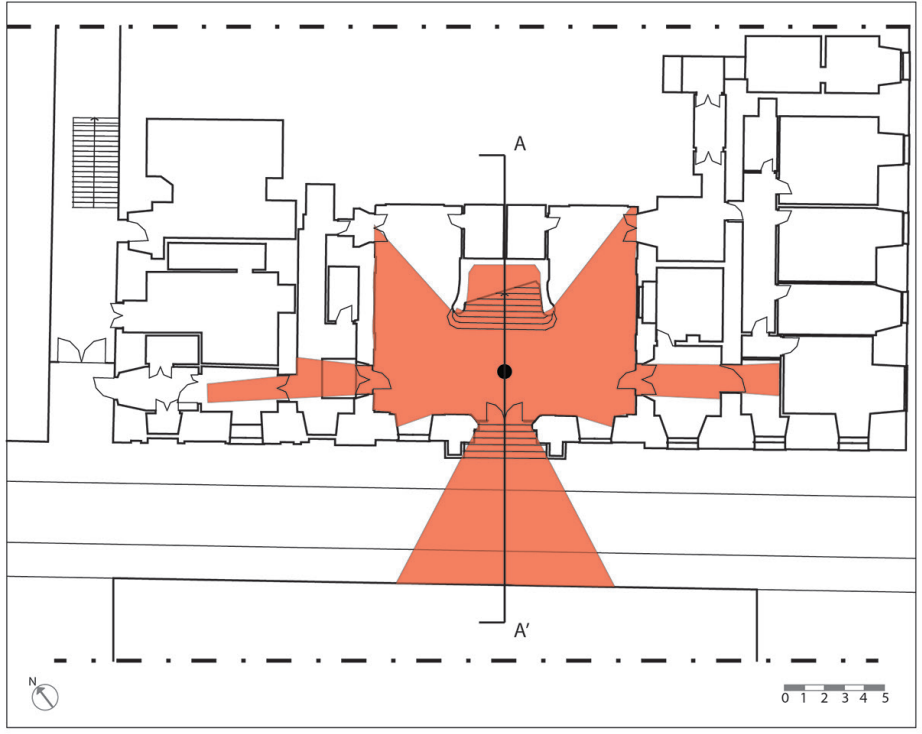

(b) 


\section{The Palace of University of Genoa}

The Palazzo of the University of Genoa was born as the seat of the Jesuit College through an agreement between an important Genoese House, the Balbi family, and the Company of Jesus. Construction began in 1633 on a project by Bartolomeo Bianco (I579- I640), with interventions by Orazio Grassi (1583-1654), rector of the college from 1646, and other protagonists of the Genoese scene that led to the construction of a building determined by an original compromise between local architecture and similar and coeval structures [I].

\section{Analysis of space perception: the isovist}

Gibson (1979) highlights how space defines a language capable of communicating information, received and reworked by the observer, to obtain useful data for the recognition of the environment [2]. One of the methods to visualize these characteristics is that which foresees the use of the isovist. The isovist is defined as the set of all the elements visible from a given observation point in space. The shape and dimensions of an isovist change with position of observation point [Benedikt 1979].

The analysis with the isovist method is a tool potentially usable in the design, as it allows to verify the visual relationship between user and space, which can help to identify some characteristics of the environment that can influence the perception.

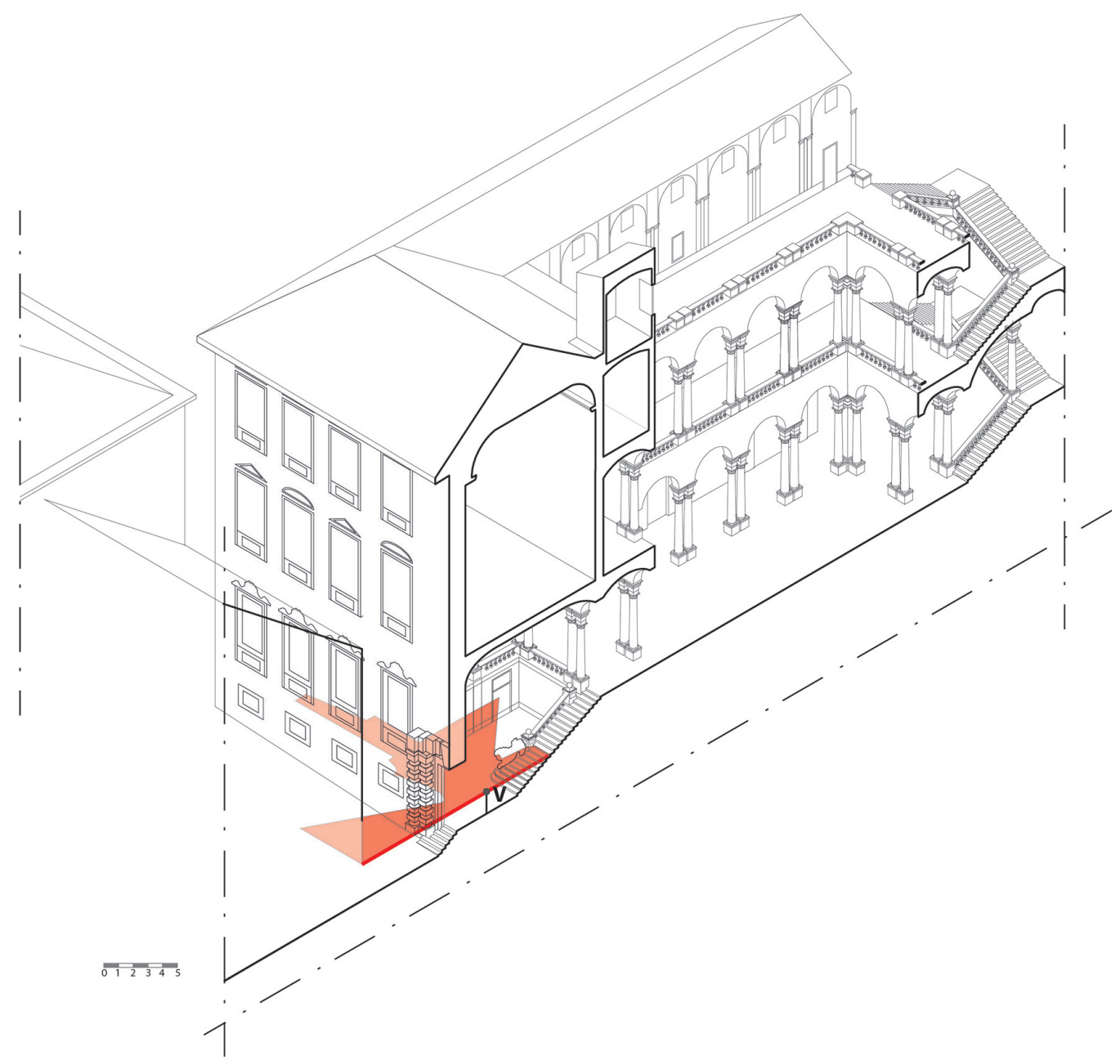


Some factors of the role of the isovist regarding orientation can be highlighted [Chen, Lin, Chen 2016]:

- relative area:This is a parameter, according to which the measurement of the visual rays and therefore the amplitude of the area varies and is evaluated as directly proportional to the feeling of security within the space.

- convexity: defines the compactness of the environment, as the degree of fragmentation of the perceived image can greatly affect the understanding of space.

Experimentations in this field have often focused on two-dimensional analysis of the isovists, focusing mainly on the planimetric vision [Nagy 20 I7]. A recent study [Ünlü et al. 2019] wish for the development of an extended approach to three-dimensionality, considering the space that has the observer's point of view as its center [3].

In the present study we have applied these principles to a university building, in analogy with previous research [Ünlü et al. 20 I9], but with peculiar characteristics for its construction in the 17th century. The atrium of the palace of the University of Genoa is the main volume on which we have focused for its access function: it is a double-height vaulted space, with a monumental eighteenth-century staircase leading to the upper levels.

The tool used to generate the figure was Grasshopper (plugin embedded in Rhinoceros since version 6.0) (fig. I a), in which is located the Isovist component that identifies the points generated by the intersection between the beam of straight lines, with origin the center of vision, and the representation in plan of the volumes within the space. Having obtained these points it is possible to use them to create the polyline that will define the perimeter of the isovist area. It is a dynamic system, since by changing the values of the coordinates of the reference point it is possible to observe the changing configuration.

We have, therefore, traced the plane figure that allows to identify the elements visible from the atrium, given the obstacles and the amplitude of the visual field (fig. Ib). The point of view has been identified near the entrance to simulate the positioning of the user in the place where the orientation phase inside the structure starts. The plan shows the complex shape of the isovist area and how the atrium is almost totally visible with the exception of some shade areas created by the imposing presence of the staircase and the pair of side lions made in the eighteenth century by Domenico Parodi.The area examined is not limited only to the atrium but is wider and allows to observe lateral spaces and external environment, of which the building in front (annex of palazzo Reale, former palazzo di Stefano Balbi) constitutes a frontal margin.

The two-dimensional method highlights significant aspects related to the observation of architectural space but does not convey enough information for its global understanding. In order to integrate the reading, the two-dimensional scheme has been positioned within an axonometric cross-section (orange background in fig. 2), so as to be able to intuit how the spatial qualities assume importance, which the two-dimensional analysis alone does not allow to properly evaluate.

\section{Panoramic photography and wayfinding}

Spatial analysis can therefore constitute progress in the isovist process. For this reason, we have tried to integrate the planimetric information with the panoramic photography tool obtained with the nodal photography procedures.

The equirectangular projection (fig. 3) provides an overall image that appears distorted in its vision as static representation, but which acquires efficacy in its dynamic exploration through $360^{\circ}$ viewer tools. The transformation into cubic projection (fig. 4) can also allow a better recognition of the elements in static images, without necessarily having to resort to the suggestive immersive dimension.

We have identified a further three-dimensional implementation in the transposition of the visible spaces taken from the panoramic photograph into a representation such as that of the axonometric cross-section (fig. 5). With the extrapolation of the main volume of the isovist in an axonometric exploded view, we can even better describe the components that 


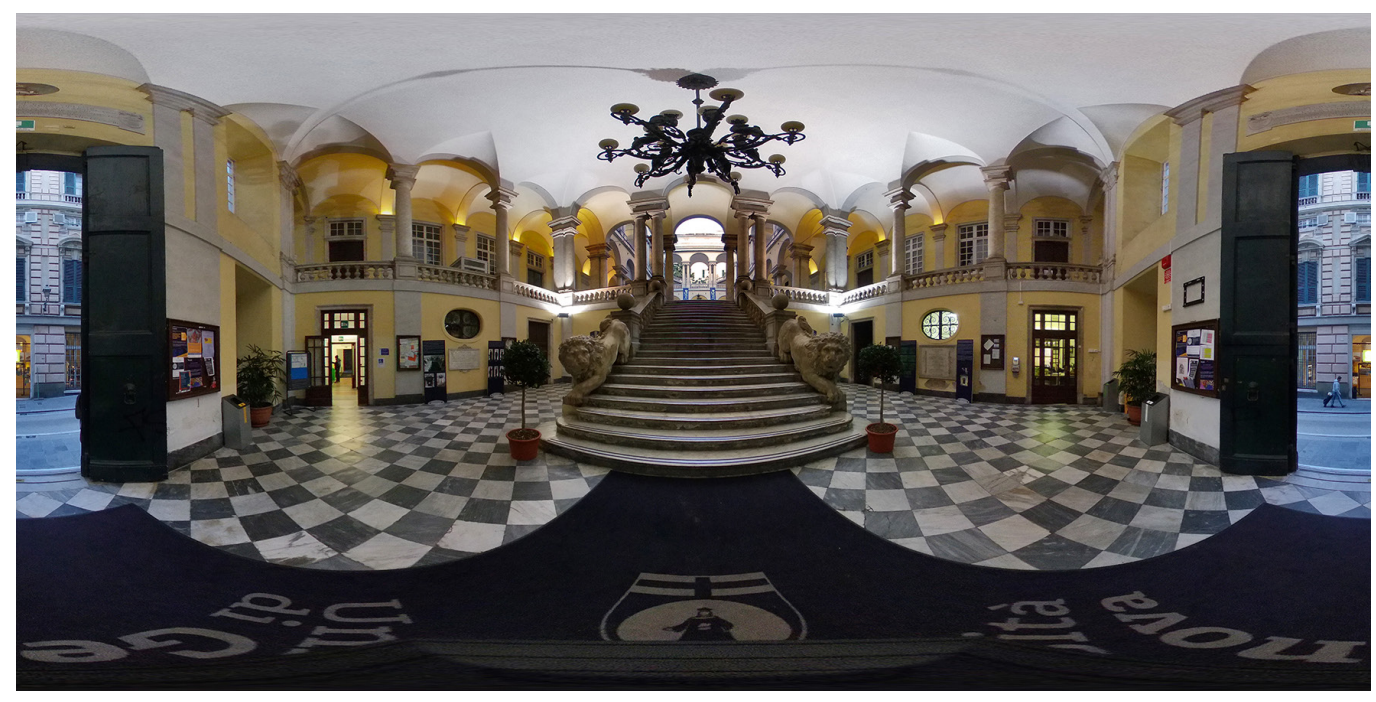

Fig. 4. Panorama in cubic projection.

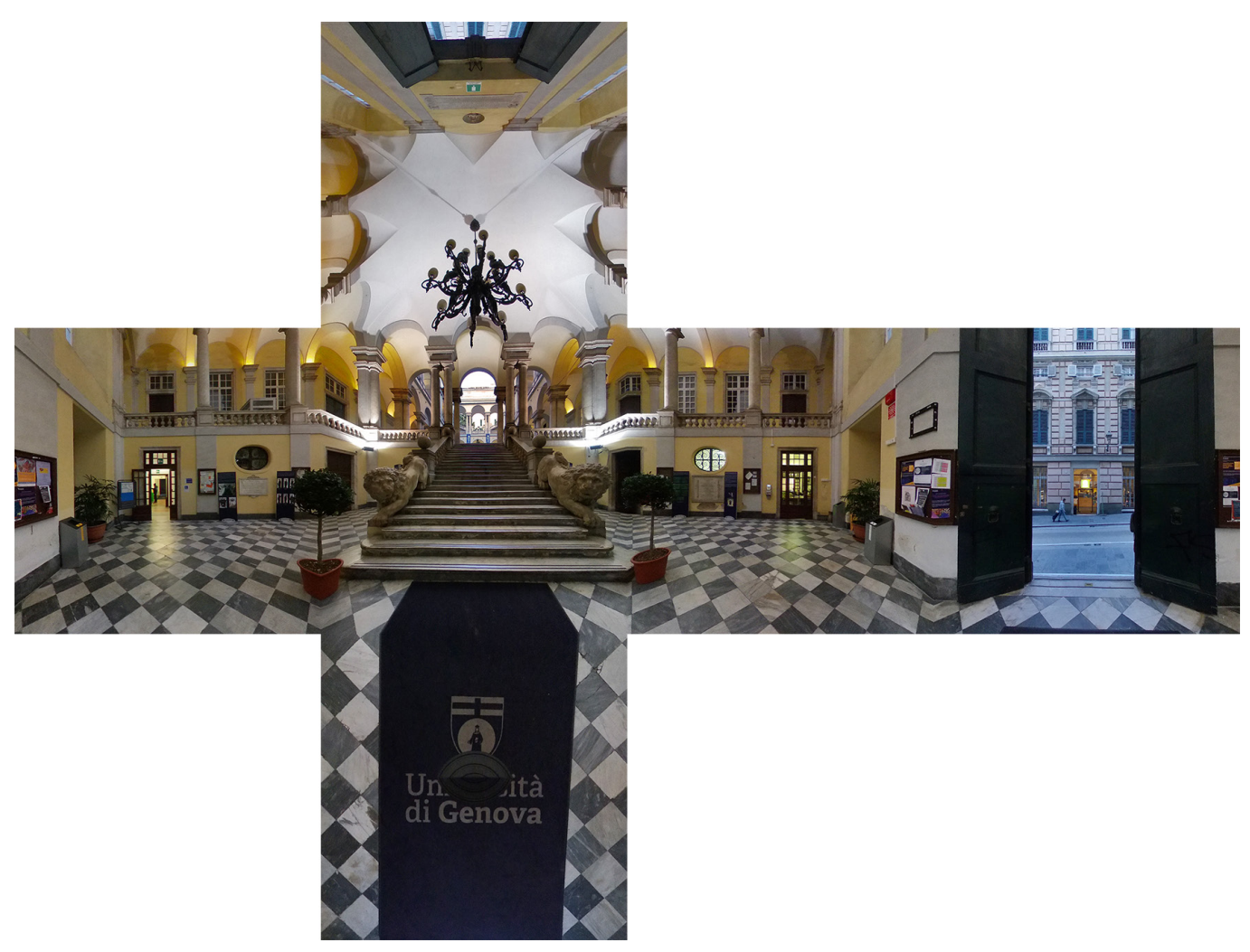


are presented to the visitor who enters the atrium (yellow backgrounds). The gaze runs along the upper side loggias of the atrium, with simple columns, to continue in the arcades of the courtyard, characterized by the most powerful supports of the paired columns, perhaps conceived on the model of the Brera jesuit college in Milan [Bösel 20 I2, pp. 7I-89].

In the upper portion of the space that frames the atrium, the sail vaults of the loggias and porch seem to stretch into the vaults of the atrium itself. It is the aforementioned axial staircase to indicate the direction that leads to the courtyard, with its gash of sky, and reaches its opposite edge with the scissor staircase that serves the two upper floors.

The representation and delimitation of the space of isovist is complex [4]; for this reason, it is necessary to resort to different representations and integrate the cross-section with longitudinal and transversal sections (figs. 5, 6). Moreover, we decided to add backgrounds of spaces which, although not visible, are easily guessed by the observer, such as the lower portions of the walls of the side loggias (under the blue line that originates at point $\mathrm{P}$ in fig. 5 ) and the completion of the walls of the portico of the courtyard, actually visible only in the cone between the projection lines (orange lines in fig. 6).

Some portions of the upper spaces are obscured by the vertical elements (see orange projection lines in fig. 5), but it is necessary to observe how it is precisely the movement of

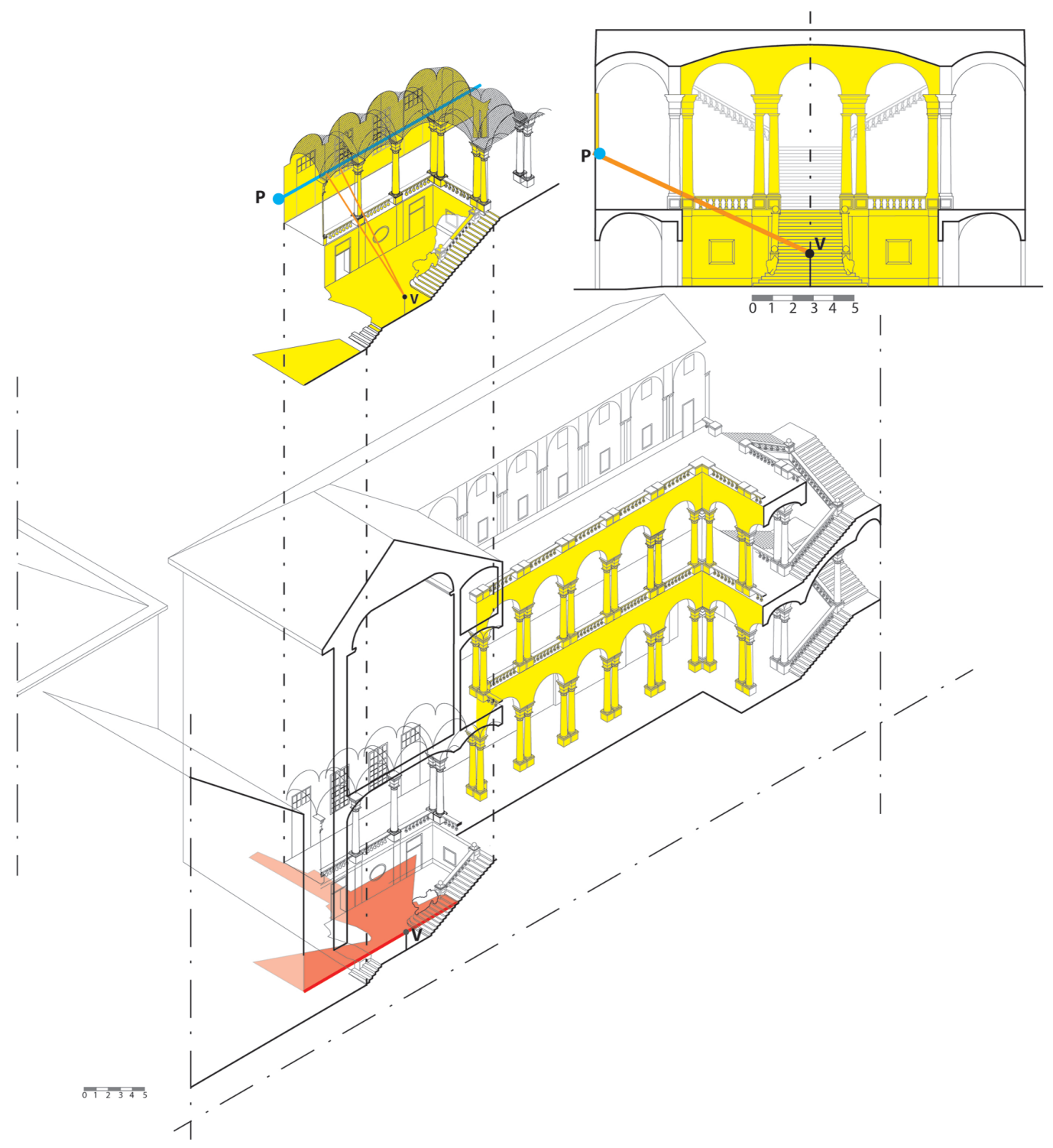


the observer that allows us to read the space in its entirety, integrating the parts that are temporarily not visible.

From the atrium, many entrances to the classrooms of the college can be perceived, overlooking the loggias and porticoes, while the windows of the fathers' houses are not visible (grey background in fig. 6), set back and overlooking the roof of the second-order arcades. The private parts in the coeval jesuit colleges are normally arranged around a second private courtyard, the absence of which in Genoa constitutes the most significant peculiarity, caused by the sloping ground, in a conformation already experienced in other local buildings [5]. For the same reason, the courtyard is in an elevated position with respect to the atrium, which therefore presents itself not only as a monumental access, but as privileged observation point for the distribution of the building, in line with some current indications of the wayfinding [Dalton, Hölscher, Spiers 20 I5].

From the courtyard on the upper level, therefore, the two orders of loggias are completely revealed, but the private parts of the college continue to remain hidden, just as if they were into another private courtyard.

\section{The Faculty of Architecture of Porto}

The analysis of some features of the Faculty of Architecture of the University of Porto, designed by Álvaro Siza (born in 1933) between 1985 and 1996, allow comparing some of the architectural devices that contribute to spatial orientation and recognition. It is important to mention that we are not referring to a single building, but an entire structure established from the pre-existent Quinta da Póvoa (beginning of the 20th century), within a large plot ceded by the University of Porto.

In this elaborate project [6], we may find important hints contributing to define the characteristics of spatial orientation and recognition. An original setting out plan (fig. 7) allows identifying a set of geometric relations that connect the new buildings with the Villa of Quinta da Póvoa and the Carlos Ramos pavillion, designed by Álvaro Siza, between 1985 and 1986, and located on the upper part of the garden.

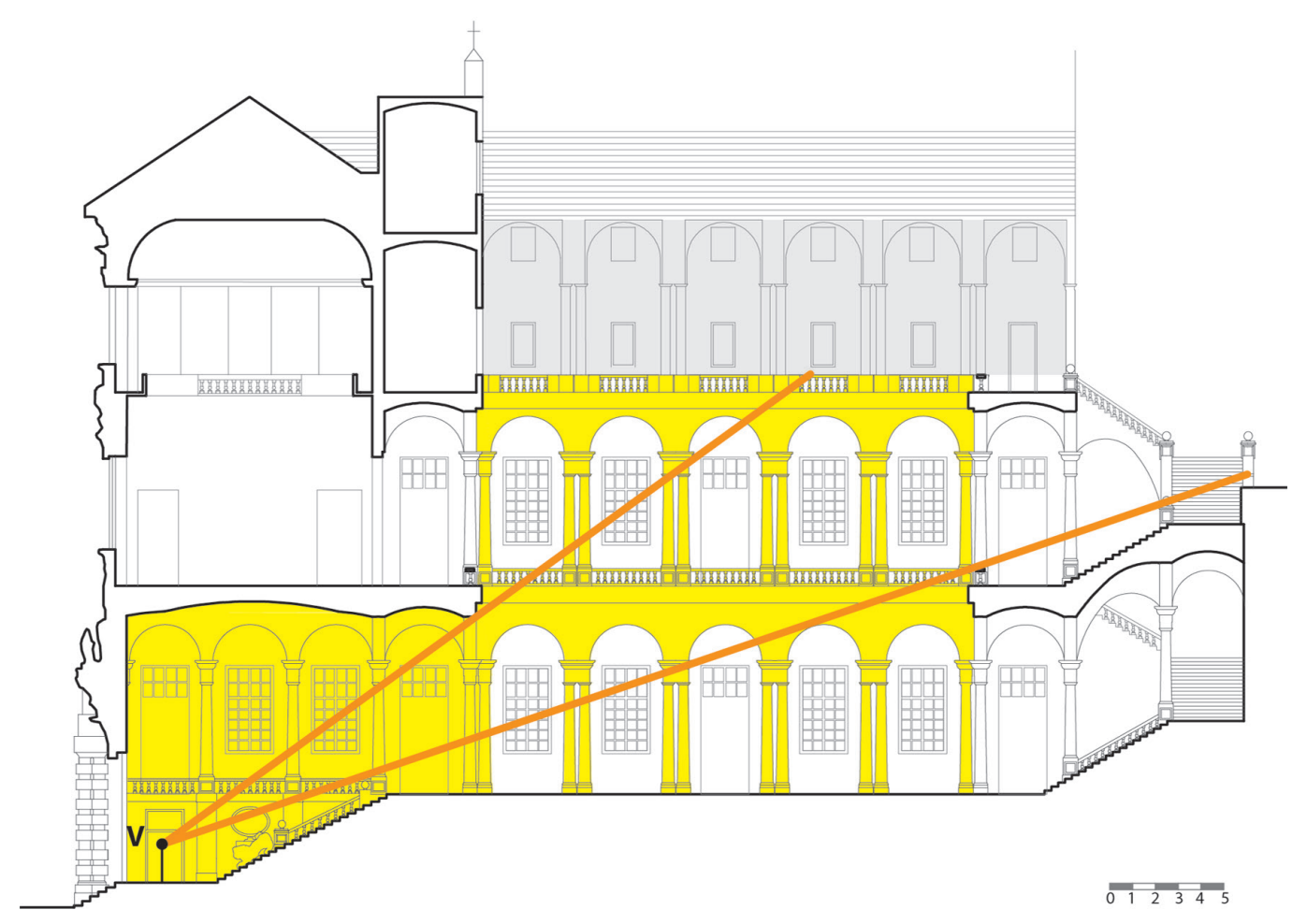


Fig. 7. Faculty of Architecture, Porto: planimetric study [Siza, Dias 2003, p. I 47].

Bottom right: Quinta da Póvoa Villa. Above a hint of the Carlos Ramos Pavilion.
Fig. 8. Level 2 plan (https:// repositorio-tematico.

up.pt). We have added the indication of the stairs (in red), the accesses (blue red), the accesses (blue (hatch) and the classrooms on the top floor of tower 3 (green hatch).
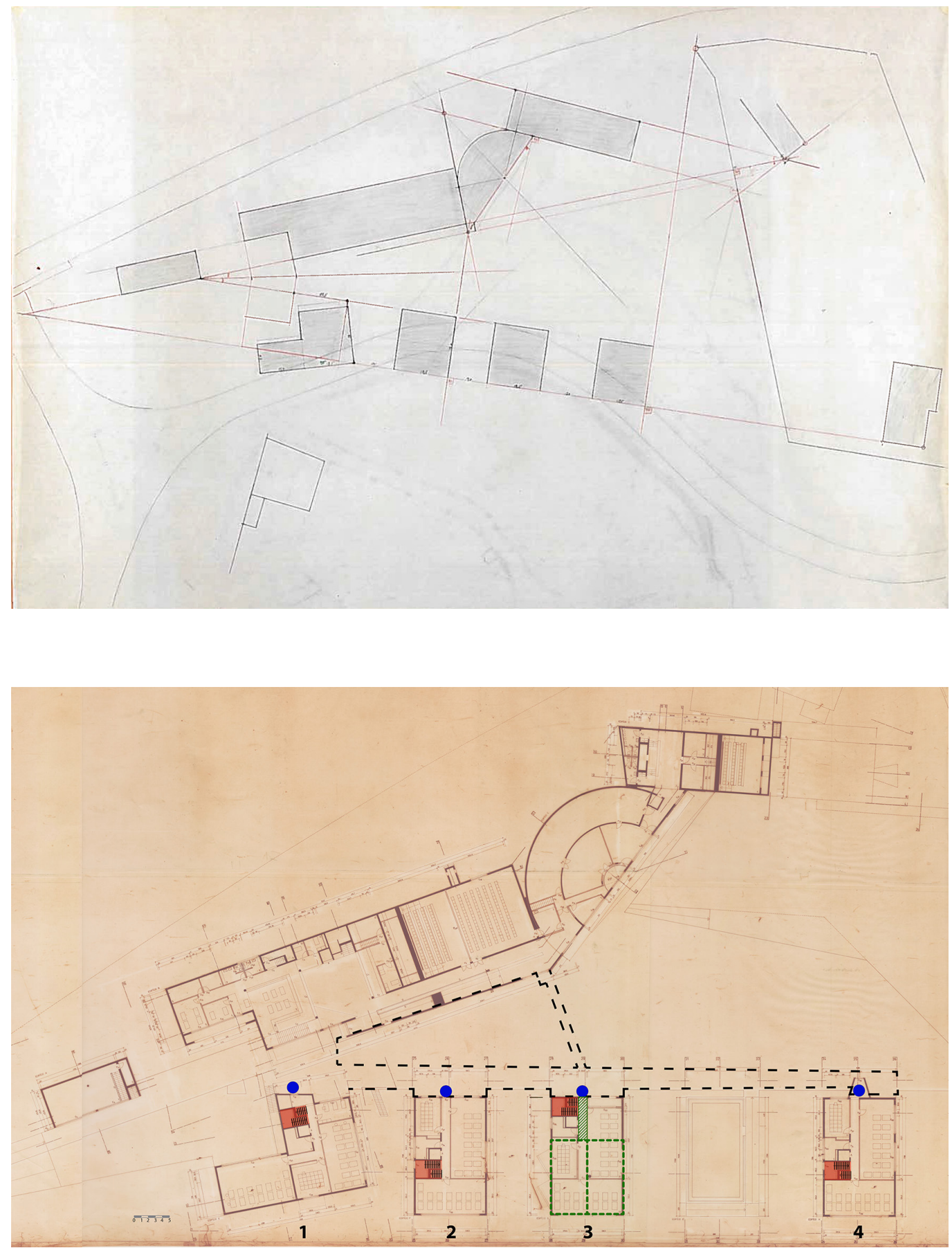
The four lone buildings facing south, where the classrooms and the teachers' offices are placed, as well as establishing a volumetric continuity with the main villa, promote a transition of scale, connecting the small twentieth-century houses, located on the riverside, and the backwards and recent towers of the city centre.

The long building to the north, which houses the administrative services, the auditoriums, the exhibition space and the library, has a different orientation, protecting from the confronting street the classrooms' towers and the central courtyard, the latter similar in its function to an entrance hall. It is, in fact, from this location that we can have a glance at the main functions of the entire complex.

The towers, similar but not equal to each other, face this immense open space, aligning with increasing height. Their entrances differ morphologically from each other, promoting an immediate recognition (fig. 8 and 9). In tower I, there is a ledge covered by a small terrace, in towers 2 and 3 the entrances are located on the facade in a different position, and in the final and highest tower 4 one can enter through a pyramidal truncated volume.

The same concept is present on the design of the towers accesses along the internal corridor at the lower level, (fig. I0) on which a variety of recessed spaces contribute to their recognition while we are walking.

A further orientation element is the narrowing of the corridor itself, which constitutes an accelerated or slowed perspective, according to the direction of the walk.

The differentiation of the spaces as an expressive feature is also accomplished on the positioning of the stairs. In towers 2 and 4, the stairs are located in the middle of the building, and in towers I and 3, we may find them, with a different configuration, positioned towards the facade (fig. 8).

The same happens with the classrooms, which are all distinct because of the different conformation and orientation of the windows. If we take as an example the two classrooms on the upper floor of tower 3, the internal symmetry, that could be suggested by the symmetrical position of the entrances, (fig. $8, \mathrm{I} I$ ) is denied by the position of the windows on the back wall and the presence of vertical brise soleils which protect from the sun the windows facing west and provide a different type of natural light.

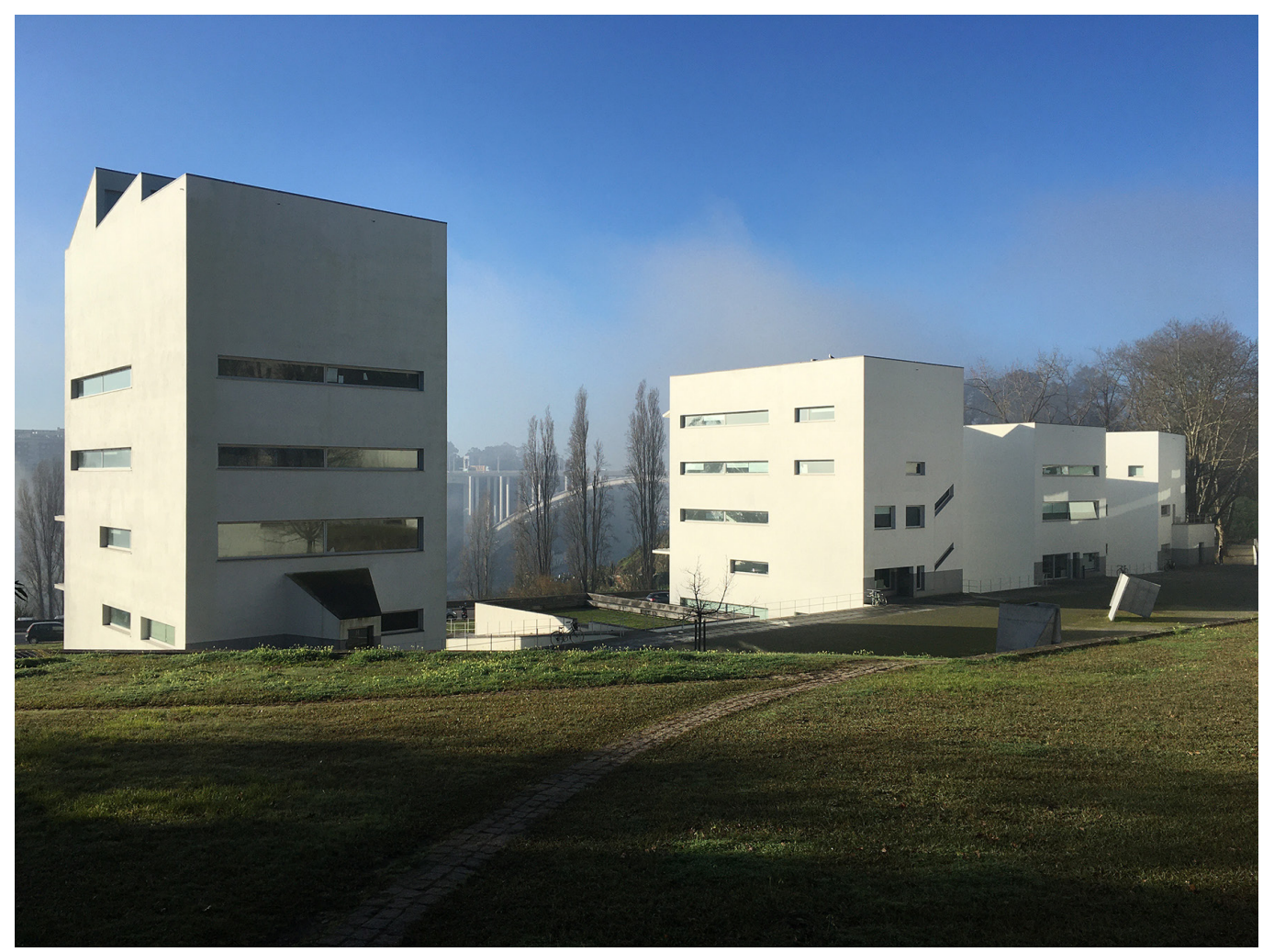




\section{Conclusions. The places of study: comparison between modern and contemporary}

The analysis of some orientation and recognizability characteristics applied to two architectures characterized by the same function allowed to make a comparison, albeit partial, on the different concept of study spaces in the past and in the present. Different methods have been applied, both quantitative and qualitative, mainly to the access areas, to verify how the visual perception in the architectural experience is also based on the recognition of the places and the orientation within them. Although limited to the considered examples and static images without consideration of the dynamic simulations, the analysis leads to the recognition of the passage from an architecture as an expression of celebration, exemplified by the seventeenth-century atrium of the palazzo of the University of Genoa -capable of highlighting public aspects and conceal the private ones- to the spatial variety offered by the accesses and the horizontal and vertical distribution of the towers, as well as by the same configuration of the classrooms found in the Faculty of Architecture of Porto, a contemporary architectural complex capable of expressing an evident attention towards the users of the spaces and to recognize the dynamic process of architectural exploration.

ig. 10. The different on the corridor at level 0 (photo by A. Castro).

Fig. I I.The classrooms on the top level of tower no. 3:

a) classroom facing south-east overlooking the Quinta da Póvoa garden and the river; b) entrances;

c) classroom facing

south-west overlooking south-west overlooking ( ce courtyard (photo by A. Castro)

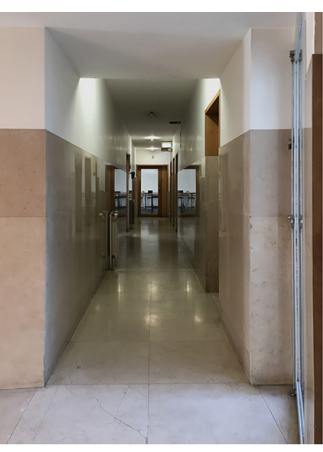

(a)

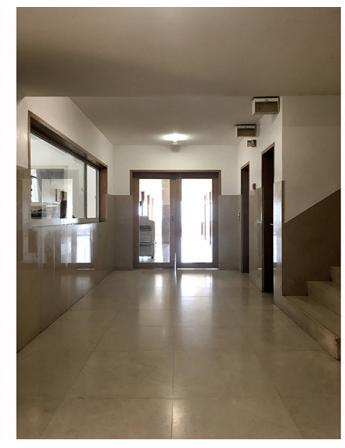

(b)

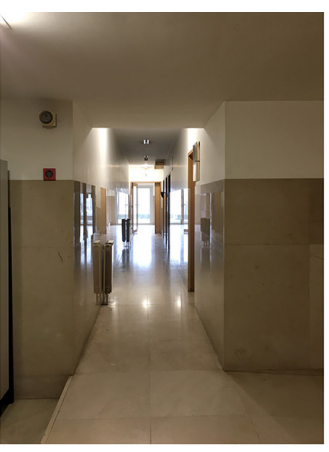

(c)

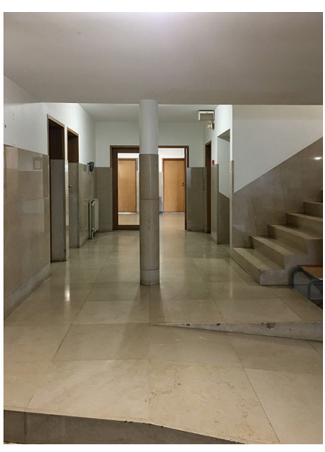

(d)

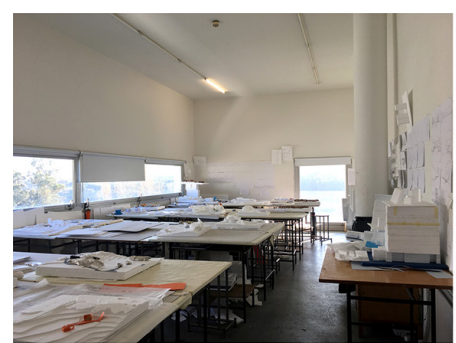

(a)

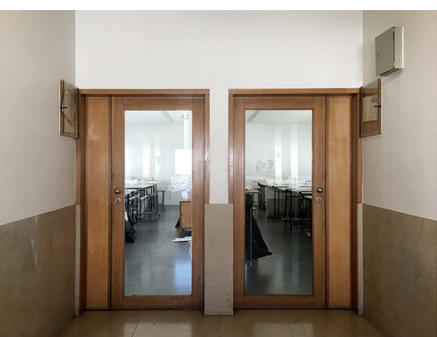

(b)

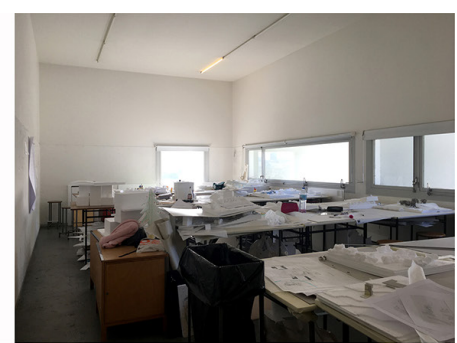

(c)

\section{Acknowledgement}

The study was partially conducted with P.R.A. 2018 (Research Projects of the University of Genoa, entitled "Representation and inclusive methods for the enhancement of architecture") coordinated by C. Càndito.

The contribution was conceived and elaborated in collaboration, but paragraph Analysis of space perception: the isovist was written by Alessandro Meloni, paragraph The Faculty of Architecture of Porto by Alexandra Castro and the rest by Cristina Càndito.

\section{Notes}

[I] For the different design versions, see: [Colmuto Zanella, De Negri 1987, pp. 209-2I I]; for Jesuit architecture: [Zamora et al. 2012], with previous bibliography.

[2] Gibson [Gibson 1979, pp. 249-250] describes how environments are composed of invariant elements, components that persist within a space and facilitate orientation

3] Spatial characteristics linked to the relationship between the height and width of the volume, its permeability, the relationship between solids and voids and the openings that provide natural lighting are highlighted: [Ünlü et al. 20 I9, cap. I.I, s.p.] 
[4] An implementation is currently being studied through an automatic link between the virtual model and panoramic photography.

[5] For example in Palazzo Doria Tursi (1564) by Domenico and Giovanni Ponzello for Nicolò Grimaldi.

[6] see: Siza, Diaz 2003; Trigueiros 1995; Márquez Cecilia, Levene 1994.

\section{References}

Benedikt Michael (1979). To Take Hold of Space: Isovists and Isovist Fields. In Environment and Planning B, 6( I), pp. 47-65.

Càndito Cristina (2005). Occhio, misura e rilievo. Gli strumenti ottici e catottrici per l'architettura e il recupero del Collegio dei Gesuiti a Genova. Firenze: Alinea (I ed. Genova 200 I).

Chen Chih-Hung, Lin Ting-Ju, Chen Chih-Yu (2016). From Isovist to Spatial Perception: Wayfinding in Historic Quarter. In Environment-Behaviour Proceedings Journal (E-BPJ), I (3), 300-3 I 0 <https://doi.org/ l 0.2 I 834/e-bpj.vl i3.374>.

Colmuto Zanella Graziella, De Negri Emmina (1987). L'architettura del collegio. In Lamera Federica, Pigafetta Giorgio. II Palazzo dell'Università di Genova. II collegio dei Gesuiti nella Strada dei Balbi. Genova: Università degli Studi di Genova, pp......

Dalton Ruth, Hölscher Christoph, Spiers Hugo J. (20I5). Navigating Complex Buildings: Cognition, Neuroscience and Architectural Design. In Gero John S. Studying Visual and Spatial Reasoning for Design Creativity. Dordrecht: Springer Netherlands, pp. 3-22. <https://doi.org/10.1007/978-94-017-9297-4_I>.

Gibson James Jerome (1979). The ecological approach to visual perception. Boston: Houghton Mifflin Company.

Golledge Reginald G. (1999). Wayfinding Behavior: cognitive mapping and other spatial processes. Baltimora:The Johns Hopkins University Press.

Lynch Kevin (1960). The image of the city. Cambridge, Massachusetts: MIT Press.

Márquez Cecilia Fernando, Levene Richard (1994). Álvaro Siza Vieira 1958- 1994. El Croquis, 68/69, 1994.

Nagy Danil (2017). View analysis with isovist. Generative Medium (blog). Catalog of lecture notes, technical tutorials, and other content from an advanced computational design course at Columbia University's Graduate School of Architecture, Planning and Preservation (GSAPP). >https://medium.com/generative-design/view-analysis-with-isovist-587fcel 49956>

Siza Álvaro, Dias Adalberto (2003). O Edifício da faculdade de Arquitectura da Universidade do Porto. Percursos do Projecto. Porto: FAUP Publicaçõe.

Trigueiros Luiz (1995). Álvaro Siza. 1986-1995. Lisboa: Editorial Blau.

Ünlü Alper, Edgü Erincik, Salgamcioglu Mehmet Emin, Çanakçioglu Gul, Yilmaz Emir Atakan (20।9). Isometric measurands on perceived spaciousness: exploring volumetric isovist. In I 2th Space Syntax Symposium, I 32. Beijing.

Zamora Álvaro, lbáñez Fernández Javier, Mainar Criado Jesus (20 I 2). La arquitectura jesuítica. Actas del Simposio Internacional. Zaragoza 9-II diciembre 2010. Zaragoza: Institución Fernando el Católico, pp. 7I-89.

\section{Authors}

Cristina Càndito, Università di Genova, cristina.candito@unige.it

Alexandra Castro, Universidade do Porto, macastro@arq.up.pt

Alessandro Meloni, Università di Genova, alessandro.meloni@edu.unige.it

To cite this chapter: Càndito Cristina, Castro Alexandra, Meloni Alessandro (2020). Rappresentazione, percezione e wayfinding. L'architettura per l'università del passato e del presente/Representation, perception and wayfinding. University Architecture of the past and present. In Arena A Arena M., Brandolino R.G., Colistra D., Ginex G., Mediati D., Nucifora S., Raffa P. (a cura di). Connettere. Un disegno per annodare e tessere. Atti del $42^{\circ}$ Convegno Internazionale dei Docenti delle Discipline della Rappresentazione/Connecting. Drawing for weaving relationships. Proceedings of the 42 th International Conference of Representation Disciplines Teachers. Milano: FrancoAngeli, pp. 1820-1841. 